\title{
Energetic and economic cost of nuclear heat - impact on the cost of desalination
}

\author{
Saied Dardour ${ }^{1,2,{ }^{*}}$ and Henri Safa ${ }^{1,3}$ \\ ${ }^{1}$ Commissariat à l'Énergie Atomique et aux Énergies Alternatives, 13108 Saint-Paul-lez-Durance Cedex, France \\ ${ }^{2}$ DEN/DER/SESI, CEA Cadarache, Bât.1222, 13108 Saint-Paul-lez-Durance Cedex, France \\ ${ }^{3}$ International Institute of Nuclear Energy, 91191 Gif-sur-Yvette Cedex, France
}

Received: 5 April 2016 / Received in final form: 8 November 2016 / Accepted: 8 November 2016

\begin{abstract}
An exploratory study has been carried out to evaluate the cost of heat supplied by a pressurized water reactor type of nuclear reactors to thermal desalination processes. In the context of this work, simplified models have been developed to describe the thermodynamics of power conversion, the energetics of multi-effect evaporation (MED), and the costs of electricity and heat cogenerated by the dual-purpose power plant. Application of these models show that, contrary to widespread belief, (nuclear-powered) MED and seawater reverse osmosis are comparable in terms of energy effectiveness. Process heat can be produced, in fact, by a relatively small increase in the core power. As fuel represents just a fraction of the cost of nuclear electricity, the increase in fuel-related expenses is expected to have limited impact on power generation economics.
\end{abstract}

\section{Introduction}

With almost 75 million cubic meter per day of worldwide installed capacity [1], desalination is the main technology used to meet water scarcity. About two third of this capacity is produced by reverse osmosis (RO) (Fig. 1). The remaining one third is produced mainly by thermal desalination plants - multi-effect evaporation (MED) and multi-stage flash (MSF), mostly in the Middle East.

Seawater desalination is an energy-intensive process. ${ }^{1}$ According to [2], the lowest energy consumption-and the closest to the minimum set by thermodynamics $\left(1.06 \mathrm{kWh} \mathrm{m}^{-3}\right)[3]-$ is achieved by RO processes equipped with energy recovery devices. Seawater RO (SWRO) electricity utilization ranges, in fact, between 4 and $7 \mathrm{~kW}_{\mathrm{e}} \mathrm{h} \mathrm{m}^{-3}$ [4]. Some plants, producing large amount of desalinated water, claim even lower energy consumption; $3.5 \mathrm{~kW}_{\mathrm{e}} \mathrm{h} \mathrm{m}^{-3}$ for Ashkelon, Israel [4]; and $2.7-3.1 \mathrm{~kW}_{\mathrm{e}} \mathrm{h} \mathrm{m}^{-3}$ (depending on temperature and membrane ageing) for Perth, Australia [5].

Thermal desalination processes consume heat, ${ }^{2}$ in addition to electricity. Heat consumption varies between 40 and $65 \mathrm{kWh}_{\mathrm{th}} \mathrm{m}^{-3}$ for MED, and $55-80 \mathrm{kWh}_{\mathrm{th}} \mathrm{m}^{-3}$ for MSF [2]. MSF's electric power consumption is

\footnotetext{
* e-mail: saied.dardour@cea.fr

${ }^{1}$ Energy is, in many cases, the largest contributor to the desalted water cost, varying from one-third to more than one-half of the cost of produced water.

2 MED's top brine temperature (TBT) generally varies between 60 and $75^{\circ} \mathrm{C}$. MSF's TBT is higher, $90-110^{\circ} \mathrm{C}$.
}

higher than MED's because of pressure drops in flashing chambers and the possible presence of brine recirculation loops [6]. MSF's pumping power varies between 2.5 and $5 \mathrm{kWh}_{\mathrm{e}} \mathrm{m}^{-3}[7]$. MED manufacturers claim specific electricity consumptions lower than $2.5 \mathrm{kWh}_{\mathrm{e}} \mathrm{m}^{-3}$.

\subsection{Power consumption: thermal desalination systems vs. membrane-based processes}

Thermal desalination systems are often coupled to power generation units to form "integrated water and power plants" (IWPPs) in which steam is supplied to the desalination unit by the power plant.

The cost of process heat provided by such plants is traditionally evaluated based on the "missed electricity production"-steam diverted to the process is no longer used for electricity production - leading, systematically, to higher energy costs for the thermal desalination processes compared to RO. MED's steam supply costs between 4 and $7 \mathrm{kWh}_{\mathrm{e}} \mathrm{m}^{-3}$ of "missed electricity production" according to [2]. If we add $1.2-2.5 \mathrm{kWh}_{\mathrm{e}} \mathrm{m}^{-3}$ of pumping energy, we end up with an equivalent electric power consumption in the range $[5.2-9.5] \mathrm{kWh}_{\mathrm{e}} \mathrm{m}^{-3}$.

Rognoni et al. [8] suggested an alternative way to evaluating the cost of heat "duly considering the benefits of cogeneration". The approach no longer views process heat as a "missed electricity production", but, rather, as "a result of a (limited) raise in the primary power" - the power released from combustion. According to this approach, the 


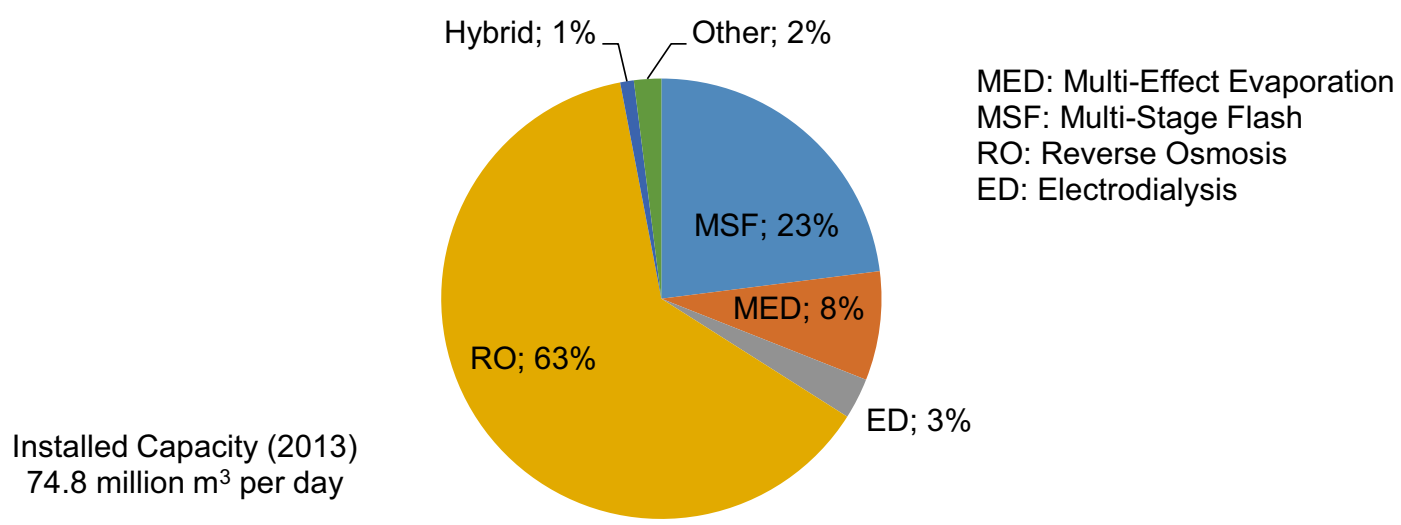

Fig. 1. Total worldwide installed capacity by technology.

energetic cost of process heat is equal to the number of $\mathrm{MW}_{\text {th }}$ added to the boiler thermal power output. Since fuel represents just a fraction of the cost of electricity, process heat is expected to be cheaper than predictions based on the traditional cost evaluation method. As a result, thermal desalination processes - precisely MED - can be potentially more cost-effective than SWRO. The authors provided two-calculation examples - MED processes fueled by coalfired power plants in India-for which the cost of desalinated water is $50 \%$ lower than SWRO's.

\section{2 “Nuclear steam" cost}

The cost of process heat depends on the contribution, to the total cost of electricity, of fuel-related expenses-a contribution widely considered to be lower for nuclearpowered electricity generators compared to fossil power plants [9]. Past studies show, in fact, that heat recovery from light water reactors is economically competitive for a number of low temperature applications, including district heating [10] and seawater desalination [11].

The study described in this paper aims at evaluating the-energetic and economic-cost of process heat, supplied by pressurized water reactor (PWR) to a thermal desalination process. The objective is to provide a basis for comparing thermal $\left(\mathrm{MED}^{3}\right)$ and membrane-based (SWRO) desalination processes in terms of energy costs. Simplified models, describing the thermodynamics of a generic PWR power conversion system, the energetics the MED process, and the costs of electricity and process heat produced by the dual-purpose plant (DPP), support this study. These models, and the results of their application, are presented and discussed in the next sections.

\section{Energetic cost of heat}

The energetic cost of heat was evaluated based on the power conversion system (PCS) architecture described in the next paragraph.

\footnotetext{
${ }^{3} \mathrm{MSF}$ is out of scope in this paper, as it consumes higher amounts of energy compared to MED.
}

\subsection{Power conversion system architecture}

Figure 2 illustrates the workflow of the PCS being modeled.

The system is basically a Rankine cycle representative of the technologies commonly applied is PWRs. Steam leaving steam generators $(\mathrm{SG})$ undergoes two expansions in the high-pressure body of the turbine $\left(\mathrm{HPT}_{1}\right.$ and $\left.\mathrm{HPT}_{2}\right)$. The fluid is then dried-up and superheated before supplying the low-pressure stages $\left(\mathrm{LPT}_{1}, \mathrm{LPT}_{2}\right.$ and $\left.\mathrm{LPT}_{3}\right)$. Liquid water extracted from the condenser $\left(\right.$ Condenser $_{2}$ ) is finally preheated and readmitted back to SG.

A steam extraction point was positioned between the outlet of $\mathrm{LPT}_{2}$ and the inlet of $\mathrm{LPT}_{3}$. This location allows for a variable quantity $(y=0-100 \%)$ of steam (the steam normally flowing through $\mathrm{LPT}_{3}$ ) to be diverted to an external process. The pressure at the steam extraction point $\left(P_{\text {SteamEx }}\right)$ may vary between 0.05 bar (pressure at the condenser) and 2.685 bar (pressure at $\mathrm{LPT}_{2}$ outlet $)$, and the temperature $\left(T_{\text {SteamEx }}\right)$ between 33 and $129^{\circ} \mathrm{C}$. The range of temperatures generally required by thermal desalination systems generally falls within these limits.

The power plant condenser was (virtually) split in two. In Condenser $_{1}$, the latent heat of condensation is transferred to the external process. Condenser ${ }_{2}$ cools the condensates down to $33^{\circ} \mathrm{C}$. The heat duty of each of the two condensers strongly depends on the quantity of steam diverted to the process.

\subsection{Thermodynamic model}

A thermodynamic model, evaluating the energetic performance of the PCS described in the previous paragraph, was developed using CEA's in-house tool ICV. ${ }^{4}$

\footnotetext{
${ }^{4}$ ICV simulates the steady-state behavior of components such as boilers, heat exchangers, pumps, compressors and turbines, as well as workflows-typically heat transfer loops and power conversion cycles - based on these components. ICV has a build-in library providing the properties of steam and water [12], including saline-water [13].
} 


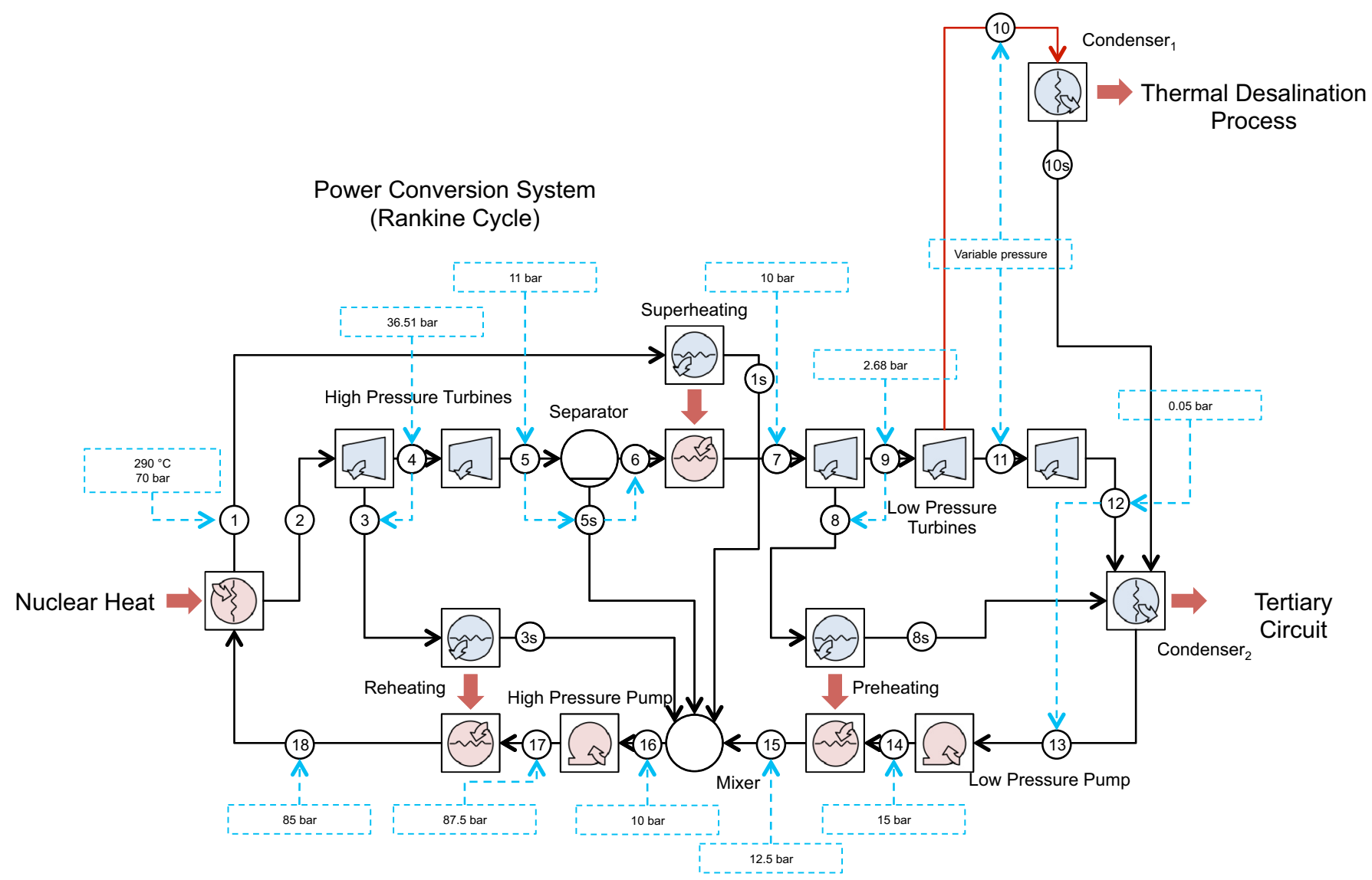

Fig. 2. Power conversion system architecture.

Table 1. Assumed pressure distribution.

Steam generator outlet

High pressure turbine 1 inlet

High pressure turbine 2 inlet

High pressure turbine 2 outlet

Separator inlet, outlets

Low pressure turbine 1 inlet

Low pressure turbine 2 inlet

Low pressure turbine 3 inlet

Condenser $_{1}$

Condenser $_{2}$

Low pressure pump outlet

Preheater outlet

Mixer outlet

High pressure pump outlet

Reheater outlet
$70 \mathrm{bar}$

36.5091 bar

11 bar

10 bar

2.685 bar

(variable)

$0.05 \mathrm{bar}$

15 bar

$12.5 \mathrm{bar}$

11 bar

87.5 bar

85 bar

The model calculates the characteristics of the 23 points of the flowsheet-temperature, pressure, steam quality, ${ }^{5}$ enthalpy, exergy and flowrate-the power of the major components of the PCS, as well as the amounts of electricity $\left(W_{\text {Elec }}\right)$ and process heat $\left(Q_{\text {Pro }}\right)$ cogenerated by the system.

\footnotetext{
${ }^{5}$ Mass of vapor to total mass in a saturated liquid--vapor mixture. Values lower than 0 or higher than 1 indicate that the fluid is either subcooled $(-100)$ or superheated $(200)$.
}

Model inputs include:

- an assumed pressure distribution within the PCS (Tab. 1); - SG outlet temperature $\left(290^{\circ} \mathrm{C}\right)$ and thermal power output $\left(\mathrm{Q}_{\mathrm{SG}}\right)$;

- the temperature at the steam extraction point $\left(T_{\text {SteamEx }}\right)$; - the fraction of steam (normally expending through $\left.\mathrm{LPT}_{3}\right)$ diverted to the external process $(y)$.

The calculation of the Rankine cycle is performed sequentially, component by component, applying the mass and energy balance equations (Eqs. (1) and $(2)^{6}$ ) to different control volumes.

$$
\begin{gathered}
\sum_{\text {in }} \dot{m}=\sum_{\text {out }} \dot{m} \\
\sum_{\text {in }} \dot{Q}+\dot{W}+\dot{m} \times\left(\bar{h}+\frac{v^{2}}{2}+g \times z\right) \\
=\sum_{\text {out }} \dot{Q}+\dot{W}+\dot{m} \times\left(\bar{h}+\frac{v^{2}}{2}+g \times z\right),
\end{gathered}
$$

$\dot{m}$, mass flowrate $(\mathrm{kg} / \mathrm{s}) ; \dot{Q}$, thermal power $(\mathrm{W}) ; \dot{W}$, mechanical power $(\mathrm{W}) ; \bar{h}$, specific enthalpy $(\mathrm{J} / \mathrm{kg}) ; v^{2} / 2$, specific kinetic energy $(\mathrm{J} / \mathrm{kg}) ; g \times z$, specific potential energy $(\mathrm{J} / \mathrm{kg}) ; g \times z$, specific potential energy $(\mathrm{J} / \mathrm{kg})$.

\footnotetext{
${ }^{6}$ In practice, the "kinetic + potential energies" term of equation (2) is neglected, leading to a simpler formulation of the energy conservation principle.
} 
Table 2. SPP (PWR $\left.2748 \mathrm{MW}_{\mathrm{th}} \rightarrow 1000 \mathrm{MW}_{\mathrm{e}}\right)$ : thermodynamic points.

\begin{tabular}{lllcccr}
\hline Point & $T\left({ }^{\circ} \mathrm{C}\right)$ & $P($ bar $)$ & $X(\%)$ & $H\left(\mathrm{~kJ} \mathrm{~kg}^{-1}\right)$ & $E\left(\mathrm{~kJ} \mathrm{~kg}^{-1} \mathrm{~K}^{-1}\right)$ & $F\left(\mathrm{~kg} \mathrm{~s}^{-1}\right)$ \\
\hline 1 & 290 & 70 & 200 & 2793.98 & 1048.97 & 139.405 \\
2 & 290 & 70 & 200 & 2793.98 & 1048.97 & 1385.06 \\
3 & 245 & 36.5091 & 93.2741 & 2685.23 & 931.684 & 245.05 \\
4 & 245 & 36.5091 & 93.2741 & 2685.23 & 931.684 & 1140.01 \\
5 & 11 & 85.9332 & 2499.41 & 729.341 & 1140.01 \\
6 & 184.07 & 11 & 100 & 2780.67 & 827.192 & 979.649 \\
7 & 275 & 10 & 200 & 2997.9 & 902.283 & 979.649 \\
8 & 145.081 & 2.685 & 200 & 2753.21 & 633.359 & 180.999 \\
9 & 145.081 & 2.685 & 200 & 2753.21 & 633.359 & 798.65 \\
10 & 80 & 0.474147 & 93.8269 & 2500.54 & 351.599 & 0 \\
11 & 80 & 0.474147 & 93.8269 & 2500.54 & 351.599 & $\underline{798.65}$ \\
12 & 32.8755 & 0.05 & 86.5162 & 2234.05 & 49.7124 & $\underline{798.65}$ \\
13 & 32.8755 & 0.05 & 0 & 137.765 & -4.22995 & 979.649 \\
14 & 32.9654 & 15 & -100 & 139.492 & -2.72166 & 979.649 \\
15 & 130.081 & 12.5 & -100 & 547.394 & 60.0595 & 979.649 \\
16 & 170.264 & 10 & -100 & 720.471 & 110.977 & 1524.47 \\
17 & 171.56 & 87.5 & -100 & 730.378 & 120.02 & 1524.47 \\
18 & 230 & 85 & -100 & 991.385 & 216.545 & 1524.47 \\
$1 \mathrm{~s}$ & 285.83 & 70 & 0 & 1267.44 & 336.615 & 139.405 \\
$3 \mathrm{~s}$ & 245 & 36.5091 & 0 & 1061.49 & 242.266 & 245.05 \\
$5 \mathrm{~s}$ & 184.07 & 11 & 781.198 & 131.569 & 160.363 \\
$8 \mathrm{~s}$ & 129.782 & 2.685 & 0.47459 & 180.999 \\
$10 \mathrm{~s}$ & 80 & 0.474147 & 0 & 345.456 & 58.7786 & 0 \\
\hline
\end{tabular}

The state of the fluid at the outlet of steam turbines and water pumps is determined applying an isentropic efficiency ( $88 \%$ for turbines and $87 \%$ for pumps):

$$
\begin{gathered}
\varepsilon_{\text {turbine }}=\frac{\bar{h}_{\text {in }}-\bar{h}_{\text {out }}}{\bar{h}_{\text {in }}-\bar{h}_{\text {out }}\left(\bar{s}_{\text {out }}=\bar{s}_{\text {in }}\right)}, \\
\varepsilon_{\text {pump }}=\frac{\bar{h}_{\text {out }}\left(\bar{s}_{\text {out }}=\bar{s}_{\text {in }}\right)-\bar{h}_{\text {in }}}{\bar{h}_{\text {out }}-\bar{h}_{\text {in }}},
\end{gathered}
$$

$\varepsilon$, isentropic efficiency; $\bar{h}_{\text {in }}$, specific enthalpy at inlet $(\mathrm{J} / \mathrm{kg})$; $\bar{s}_{\text {in }}$, specific entropy at inlet $(\mathrm{J} / \mathrm{kg} / \mathrm{K}) ; \bar{h}_{\text {out }}$, specific enthalpy at outlet $(\mathrm{J} / \mathrm{kg}) ; \bar{s}_{\text {out }}$, specific entropy at outlet $(\mathrm{J} / \mathrm{kg} / \mathrm{K}) ; \bar{h}_{\text {out }}\left(\bar{s}_{\text {out }}=\bar{s}_{\text {in }}\right)$, specific enthalpy at outlet for a constant-entropy transformation.

The following assumptions were also made:

- Steam admitted to different heat exchangers is assumed to leave all its latent heat to the fluid flowing on the secondary side of the exchanger.

- A fixed pinch point temperature difference of $15^{\circ} \mathrm{C}$ was systematically applied to determine the outlet fluid temperature on the secondary side.

- Energy losses ${ }^{7}$ are not taken into account (the calculated "net" power and heat outputs are actually "gross" power and heat outputs).

\footnotetext{
7 Thermal losses at heat exchangers. Mechanical losses at pumps, turbines and generators. Electrical power consumption, internal to the power plant and the external process.
}

Table 3. SPP (PWR $\left.2748 \mathrm{MW}_{\text {th }} \rightarrow 1000 \mathrm{MW}_{\mathrm{e}}\right)$ : mechanical and thermal powers.

\begin{tabular}{ll}
\hline Component & Power (MW) \\
\hline Steam generators & 2747.99 \\
High pressure turbine 1 & -150.624 \\
High pressure turbine 2 & -211.837 \\
Low pressure turbine 1 & -239.709 \\
Low pressure turbine 2 & -201.796 \\
Low pressure turbine 3 & -212.827 \\
Condenser ${ }_{1}$ (Process) & 0 \\
Condenser 2 (Tertiary circuit) & -1747.99 \\
Low pressure pump & 1.69183 \\
High pressure pump & 15.102 \\
Sum & $-1.14 \times 10^{-13}$ \\
Net power output & -1000 \\
Power conversion efficiency (\%) & $\underline{36.3902}$ \\
\hline
\end{tabular}

\subsection{Energetic performance of the PCS}

Tables 2 and 3 show the characteristics of a $2748 \mathrm{MW}_{\text {th }}$ singlepurpose plant (SPP) generating $1000 \mathrm{MW}_{\mathrm{e}}$ of electricity.

The contribution of steam turbines to SPP's electricity output is shown in Figure 3. $\mathrm{LPT}_{3}$ delivers $213 \mathrm{MW}_{\mathrm{e}}$ of mechanical power, which represents $21 \%$ of the total electricity output. 


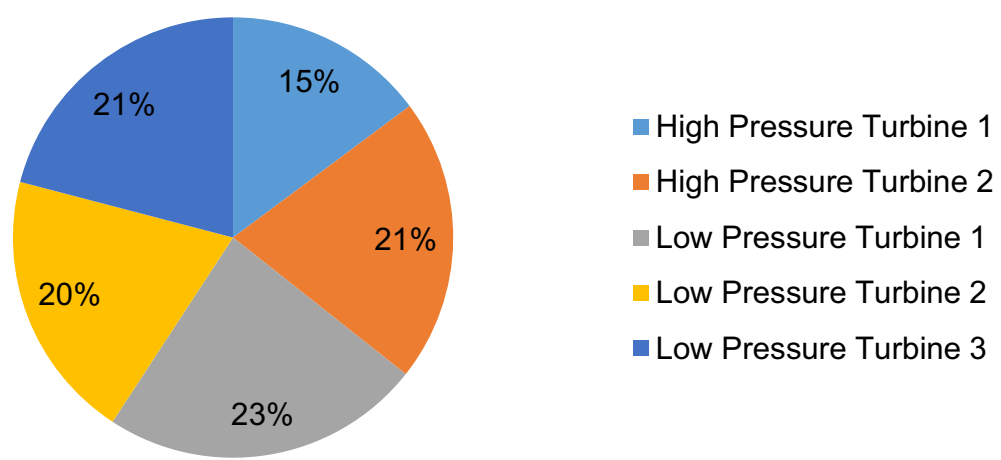

Fig. 3. Contribution of steam turbines to SPP's electricity output.

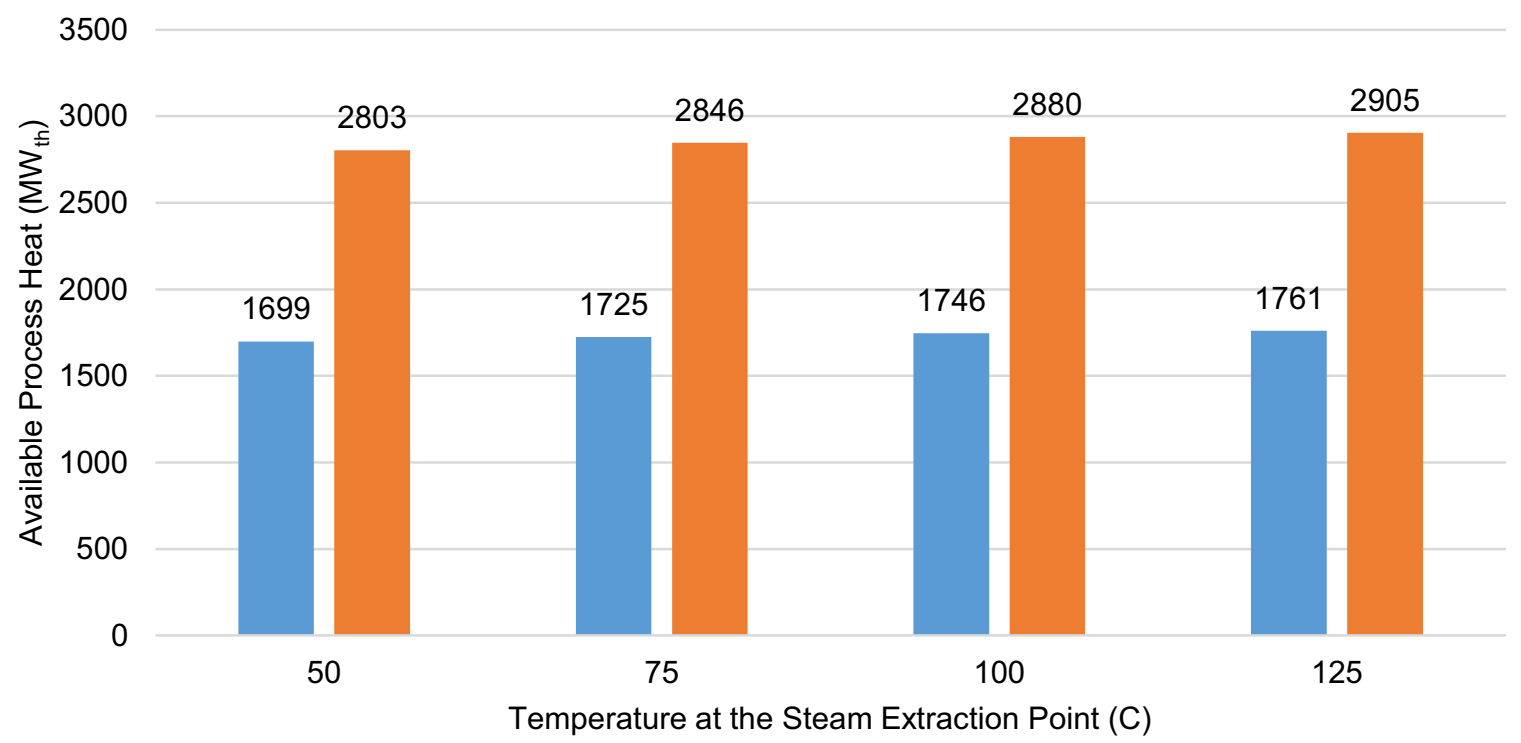

Fig. 4. Available heat for the external process vs. temperature at the steam extraction point. Blue bar: PWR $1000 \mathrm{MWe}$ (2748 MWth); orange bar: PWR 1650 MWe (4534 MWth).

If all the steam normally flowing towards this turbine is redirected to the external process $\left(T_{\text {SteamEx }}=80^{\circ} \mathrm{C}\right)$, the plant would generate $787 \mathrm{MW}_{\mathrm{e}}$ of electricity and $1730 \mathrm{MW}_{\text {th }}$ of process heat. The reactor's process heat generation capacity depends, in fact, on the core power, and on the temperature at the steam extraction point, as shown in Figure 4.

Now, if only a portion of this steam - exactly $57.8 \%$ - is diverted, the plant would produce $877 \mathrm{MW}_{\mathrm{e}}$ of electricity and $1000 \mathrm{MW}_{\text {th }}$ of heat. The characteristics of configuration - we will call it $\mathrm{DPP}_{1}$ (dual-purpose plant) - are listed in Tables 4 and 5.

The differences between $\mathrm{SPP}$ and $\mathrm{DPP}_{1}$ are highlighted (underlined) in Tables 2-5. The two Rankine cycles have identical characteristics except for points 10-12. In $\mathrm{DPP}_{1}$, turbine $\mathrm{LPT}_{3}$ is partly bypassed-the exergy of the rerouted steam is later "destructed" in Condenser $_{1}$ - resulting in a $123 \mathrm{MW}_{\mathrm{e}}$ decrease in power generation compared to SPP.

The number of $\mathrm{MW}_{\mathrm{e}}$ of electricity production lost for each $\mathrm{MW}_{\text {th }}$ supplied to the external process $\left(123 \mathrm{~kW}_{\mathrm{e}}\right.$ per $\mathrm{MW}_{\text {th }}$ in the case of $\mathrm{DPP}_{1}$ ) is a traditional measure of the energetic cost of process heat. This measure will be referred to as the "W-cost of heat" or WCH:

$$
\mathrm{WCH}=\left[\frac{\Delta \dot{W}_{\text {Elec }}}{\dot{Q}_{\text {Pro }}}\right]_{\dot{Q}_{\mathrm{SG}}=\text { Constant }} .
$$

This "loss" in electricity production can be avoided by increasing the thermal power of the core. To keep the electricity generation capacity at $1000 \mathrm{MW}_{\mathrm{e}}$ - and the heat production level at $1000 \mathrm{MW}_{\mathrm{th}}-\mathrm{SG}$ have to deliver an additional $338 \mathrm{MW}_{\text {th }}$. The portion of diverted steam has also to be adjusted (51.5\%). This configuration -we will call it $\mathrm{DPP}_{2}$ (Tabs. 6 and 7 ) - not only offers higher power conversion efficiency (32.40\%) compared to $\mathrm{DPP}_{1}$ $(31.91 \%)$, but also results in lower heat cost, as we will see in Section 2.

The number of $\mathrm{MW}_{\text {th }}$ added to core power, per $\mathrm{MW}_{\text {th }}$ supplied to the external process $\left(338 \mathrm{~kW}_{\text {th }}\right.$ per $\mathrm{MW}_{\text {th }}$ in the case of $\mathrm{DPP}_{2}$ ) provides an alternative measure of the energetic cost of steam - we will call it the "Q-cost of heat" or QCH:

$$
\mathrm{QCH}=\left[\frac{\Delta \dot{Q}_{\mathrm{SG}}}{\dot{Q}_{\text {Pro }}}\right]_{\dot{W}_{\text {Elec }}=\text { Constant }},
$$


Table 4. $\mathrm{DPP}_{1}\left(\mathrm{PWR} 2748 \mathrm{MW}_{\text {th }} \rightarrow 877 \mathrm{MW}_{\mathrm{e}}+1000 \mathrm{MW}_{\text {th }}\right.$ at $\left.80^{\circ} \mathrm{C}\right)$ : thermodynamic points.

\begin{tabular}{lllcccc}
\hline Point & $T\left({ }^{\circ} \mathrm{C}\right)$ & $P(\mathrm{bar})$ & $X(\%)$ & $H\left(\mathrm{~kJ} \mathrm{~kg}^{-1}\right)$ & $E\left(\mathrm{~kJ} \mathrm{~kg}^{-1} \mathrm{~K}^{-1}\right)$ & $F\left(\mathrm{~kg} \mathrm{~s}^{-1}\right)$ \\
\hline 1 & 290 & 70 & 200 & 2793.98 & 1048.97 & 139.405 \\
2 & 290 & 70 & 200 & 2793.98 & 1048.97 & 1385.06 \\
3 & 245 & 36.5091 & 93.2741 & 2685.23 & 931.684 & 245.05 \\
4 & 245 & 36.5091 & 93.2741 & 2685.23 & 931.684 & 1140.01 \\
5 & 184.07 & 11 & 85.9332 & 2499.41 & 729.341 & 1140.01 \\
6 & 184.07 & 11 & 100 & 2780.67 & 827.192 & 979.649 \\
7 & 275 & 10 & 200 & 2997.9 & 902.283 & 979.649 \\
8 & 145.081 & 2.685 & 200 & 2753.21 & 633.359 & 180.999 \\
9 & 145.081 & 2.685 & 200 & 2753.21 & 633.359 & 798.65 \\
10 & 80 & 0.474147 & 93.8269 & 2500.54 & 351.599 & $\underline{461.769}$ \\
11 & 80 & 0.474147 & 93.8269 & 2500.54 & 351.599 & $\underline{336.881}$ \\
12 & 32.8755 & 0.05 & 86.5162 & 2234.05 & 49.7124 & 336.881 \\
13 & 32.8755 & 0.05 & 0 & 137.765 & -4.22995 & 979.649 \\
14 & 32.9654 & 15 & -100 & 139.492 & -2.72166 & 979.649 \\
15 & 130.081 & 12.5 & -100 & 547.394 & 60.0595 & 979.649 \\
16 & 170.264 & 10 & -100 & 720.471 & 110.977 & 1524.47 \\
17 & 171.56 & 87.5 & -100 & 730.378 & 120.02 & 1524.47 \\
18 & 230 & 85 & -100 & 991.385 & 216.545 & 1524.47 \\
$1 \mathrm{~s}$ & 285.83 & 70 & 0 & 1267.44 & 336.615 & 139.405 \\
$3 \mathrm{~s}$ & 245 & 36.5091 & 0 & 1061.49 & 242.266 & 245.05 \\
$5 \mathrm{~s}$ & 184.07 & 11 & 781.198 & 131.569 & 160.363 \\
$8 \mathrm{~s}$ & 129.782 & 2.685 & 0.545 .456 & 180.999 \\
$10 \mathrm{~s}$ & 80 & 0.474147 & 0 & 334.949 & 14.3207 & $\underline{461.769}$ \\
\hline
\end{tabular}

QCH is simply obtained dividing WCH by SPP's power conversion efficiency.

The increase in core power considered in this study is purely conceptual. ${ }^{8}$ Adopting QCH as a measure of the energetic cost of steam makes it possible, in fact, to take into account the advantages cogeneration offers.

Figure 5 shows how WCS and QCH vary with $T_{\text {SteamEx }}$. At $75^{\circ} \mathrm{C}$, each $\mathrm{MW}_{\mathrm{th}} \mathrm{h}$ of thermal power supplied to the process costs $111 \mathrm{~kW}_{\mathrm{e}} \mathrm{h}$ of electricity. At $100^{\circ} \mathrm{C}$, the cost increases to $169 \mathrm{~kW}_{\mathrm{e}} \mathrm{h} \mathrm{MW} \mathrm{Hh}^{-1}(\times 1.5)$, and at $125^{\circ} \mathrm{C}$ it reaches $223 \mathrm{~kW}_{\mathrm{e}} \mathrm{h} \mathrm{MW}_{\mathrm{th}} \mathrm{h}^{-1}(\times 2)$.

The energetic cost of heat depends, actually, on the enthalpy at the steam extraction point, which is a function of the level of temperature required by the external process (Eq. (7)).

$\mathrm{WCH}\left(T_{\text {SteamEx }}\right)=\frac{\bar{h}_{\text {SteamEx }}\left(T_{\text {SteamEx }}\right)-\bar{h}_{\mathrm{LPT}_{3, \text { outlet }}}}{\bar{h}_{\text {SteamEx }}\left(T_{\text {SteamEx }}\right)-\bar{h}_{\text {Consenser }_{1, \text { outlet }}}}$.

\section{Economic cost of heat}

\subsection{Single-purpose plant}

To evaluate the cost of electricity relative a single-purpose plant, we first calculate the minimal annual cash in-generated from

\footnotetext{
${ }^{8}$ Increasing the fission power of the core is not always technologically feasible, especially for plants that are already "big".
}

Table 5. $\mathrm{DPP}_{1}\left(\mathrm{PWR} 2748 \mathrm{MW}_{\mathrm{th}} \rightarrow 877 \quad \mathrm{MW}_{\mathrm{e}}+1000\right.$ $\mathrm{MW}_{\text {th }}$ at $80^{\circ} \mathrm{C}$ ): mechanical and thermal powers.

\begin{tabular}{|c|c|}
\hline Component & Power (MW) \\
\hline Steam generators & 2747.99 \\
\hline High pressure turbine 1 & -150.624 \\
\hline High pressure turbine 2 & -211.837 \\
\hline Low pressure turbine 1 & -239.709 \\
\hline Low pressure turbine 2 & -201.796 \\
\hline Low pressure turbine 3 & -89.7732 \\
\hline Condenser $_{1}$ (Process) & -1000 \\
\hline Condenser $_{2}$ (Tertiary circuit) & $-\overline{871.044}$ \\
\hline Low pressure pump & $1 . \overline{69183}$ \\
\hline High pressure pump & 15.102 \\
\hline Sum & $1.25 \times 10^{-13}$ \\
\hline Net power output & -876.946 \\
\hline Power conversion efficiency (\%) & 31.9123 \\
\hline
\end{tabular}

the sale of electricity - required to have a positive NPV.NPV refers here to the net present value of future free cash flows:

- annual expenses related to, construction, purchase of nuclear fuel, operation and maintenance (O\&M), and decommissioning, on one hand;

- annual revenue generated from the sale of electricity, on the other hand. 
Table 6. $\mathrm{DPP}_{2}\left(\mathrm{PWR} 3086 \mathrm{MW}_{\mathrm{th}} \rightarrow 1000 \mathrm{MW}_{\mathrm{e}}+1000 \mathrm{MW}_{\text {th }}\right.$ at $\left.80^{\circ} \mathrm{C}\right)$ : thermodynamic points.

\begin{tabular}{lllcccc}
\hline Point & $T\left({ }^{\circ} \mathrm{C}\right)$ & $P($ bar $)$ & $X(\%)$ & $H\left(\mathrm{~kJ} \mathrm{~kg}^{-1}\right)$ & $E\left(\mathrm{~kJ} \mathrm{~kg}^{-1} \mathrm{~K}^{-1}\right)$ & $F\left(\mathrm{~kg} \mathrm{~s}^{-1}\right)$ \\
\hline 1 & 290 & 70 & 200 & 2793.98 & 1048.97 & 156.56 \\
2 & 290 & 70 & 200 & 2793.98 & 1048.97 & 1555.5 \\
3 & 245 & 36.5091 & 93.2741 & 2685.23 & 931.684 & 275.204 \\
4 & 245 & 36.5091 & 93.2741 & 2685.23 & 931.684 & 1280.29 \\
5 & 184.07 & 11 & 85.9332 & 2499.41 & 729.341 & 1280.29 \\
6 & 184.07 & 11 & 100 & 2780.67 & 827.192 & 1100.2 \\
7 & 275 & 10 & 200 & 2997.9 & 902.283 & 1100.2 \\
8 & 145.081 & 2.685 & 200 & 2753.21 & 633.359 & 203.272 \\
9 & 145.081 & 2.685 & 200 & 2753.21 & 633.359 & 896.926 \\
10 & 80 & 0.474147 & 93.8269 & 2500.54 & 351.599 & 461.769 \\
11 & 80 & 0.474147 & 93.8269 & 2500.54 & 351.599 & 435.158 \\
12 & 32.8755 & 0.05 & 86.5162 & 2234.05 & 49.7124 & 435.158 \\
13 & 32.8755 & 0.05 & 0 & 137.765 & -4.22995 & 1100.2 \\
14 & 32.9654 & 15 & -100 & 139.492 & -2.72166 & 1100.2 \\
15 & 130.081 & 12.5 & -100 & 547.394 & 60.0595 & 1100.2 \\
16 & 170.264 & 10 & -100 & 720.471 & 110.977 & 1712.06 \\
17 & 171.56 & 87.5 & -100 & 730.378 & 120.02 & 1712.06 \\
18 & 230 & 85 & -100 & 991.385 & 216.545 & 1712.06 \\
$1 \mathrm{~s}$ & 285.83 & 70 & 0 & 1267.44 & 336.615 & 156.56 \\
$3 \mathrm{~s}$ & 245 & 36.5091 & 0 & 1061.49 & 242.266 & 275.204 \\
$5 \mathrm{~s}$ & 184.07 & 11 & 781.198 & 131.569 & 180.097 \\
$8 \mathrm{~s}$ & 129.782 & 2.685 & 0.545 .456 & 58.7786 & 203.272 \\
$10 \mathrm{~s}$ & 80 & 0.474147 & 0 & 334.949 & 14.3207 & 461.769 \\
\hline
\end{tabular}

Table 7. $\mathrm{DPP}_{2}\left(\mathrm{PWR} 3086 \mathrm{MW}_{\mathrm{th}} \rightarrow 1000 \mathrm{MW}_{\mathrm{e}}+1000\right.$ $\mathrm{MW}_{\text {th }}$ at $\left.80^{\circ} \mathrm{C}\right)$ : mechanical and thermal powers.

\begin{tabular}{ll}
\hline Component & Power $(\mathrm{MW})$ \\
\hline Steam generators & 3086.14 \\
High pressure turbine 1 & -169.159 \\
High pressure turbine 2 & -237.905 \\
Low pressure turbine 1 & -269.206 \\
Low pressure turbine 2 & -226.627 \\
Low pressure turbine 3 & -115.962 \\
Condenser ${ }_{1}$ (Process) & -1000 \\
Condenser 2 (Tertiary circuit) & -1086.14 \\
Low pressure pump & 1.90001 \\
High pressure pump & 16.9604 \\
Sum & $1.31 \times 10^{-12}$ \\
Net power output & -1000 \\
Power conversion efficiency (\%) & 32.4029 \\
\hline
\end{tabular}

The minimal annual cash in (ci) is related to cash outflows by equation (8):

$-\mathrm{co}_{\text {cst }} \times \operatorname{npv}(1 \$, \mathrm{cst})+\left(\mathrm{ci}-\mathrm{co}_{\mathrm{opr}}\right) \times \operatorname{npv}(1 \$$, opr $)$

$-\operatorname{co}_{\mathrm{dcm}} \times \operatorname{npv}(1 \$, \mathrm{dcm})=0$, $\mathrm{co}_{\text {cst }}$, annual cash out, construction period, (\$); npv (1\$, cst), NPV of a fixed expense of $1 \$$ per year, spent during the construction period, (\$); ci, annual revenue generated from the sale of electricity, $(\$) ; \mathrm{co}_{\mathrm{opr}}$, annual expenses related to fuel and O\&M, economic lifetime of the plant, $(\$) ; n p v(1 \$$, opr), NPV of a fixed expense of $1 \$$ per year, spent over the economic lifetime of the plant; $\mathrm{co}_{\mathrm{dcm}}$, annual cash out, decommissioning period, $(\$) ; \mathrm{npv}(1 \$, \mathrm{dcm}), \mathrm{NPV}$ of a fixed expense of $1 \$$ per year, spent during the decommissioning period.

NPV terms of equation (8) are estimated based on a fixed discount rate $(r)$ applicable for the three periods ${ }^{9}$ :

$$
\operatorname{npv}(1 \$, \text { period })=\sum_{Y=Y_{\text {beginning,period }}}^{Y_{\text {end,period }}}(1+r)^{-Y} .
$$

Equation (8) assumes fixed values of future inflows and outflows over the three key phases of the lifetime of the plant: construction (cst), operation (opr) and decommissioning $(\mathrm{dcm})$.

$\overline{9}$ Traditionally, the rate used in discounted cash flow analysis is adjusted for risk, period by period. This is not the case for this exercise. 


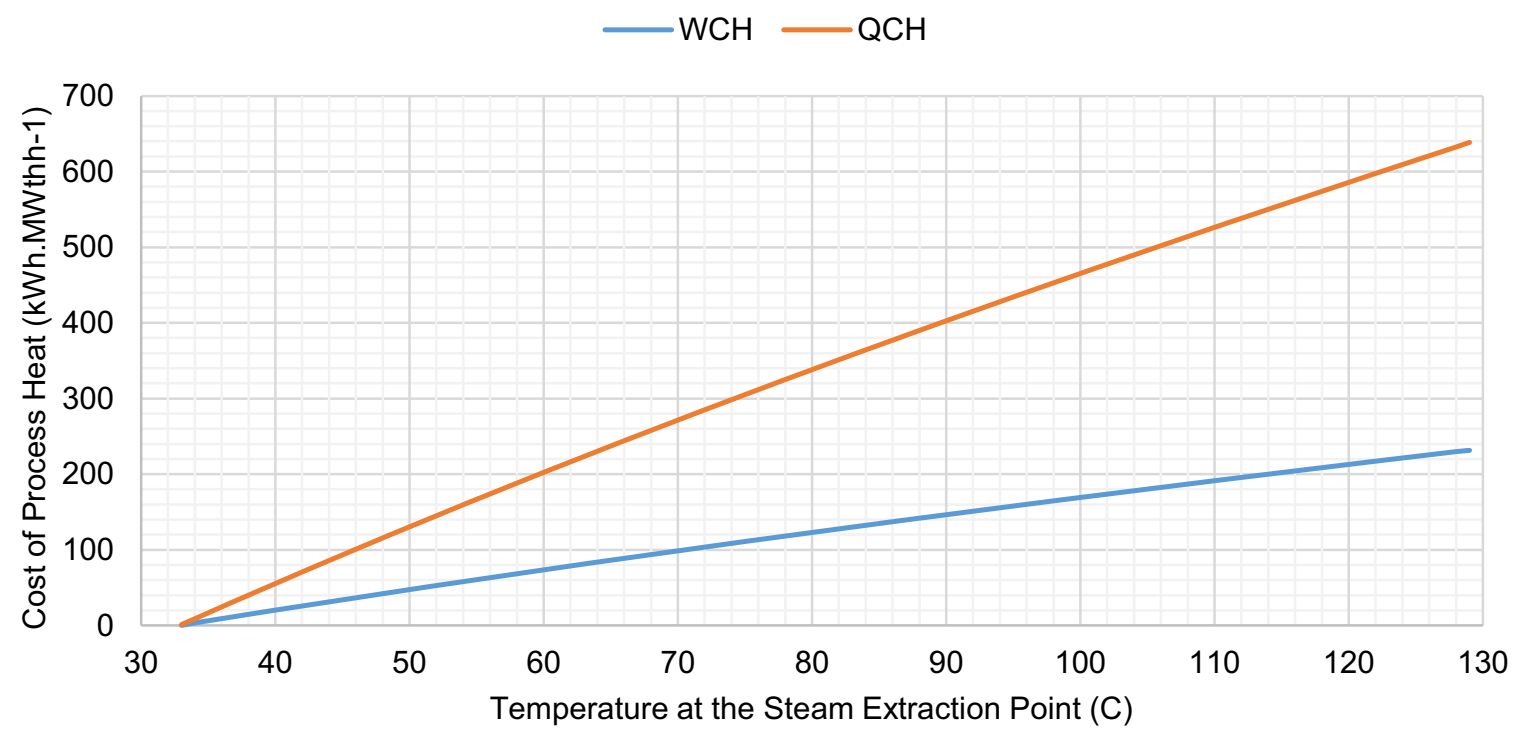

Fig. 5. WCH and QCH vs. temperature at the steam extraction point.

Annual expenses ${ }^{10}$ (construction, fuel, O\&M and decommissioning) are evaluated on the basis of specific costs: - The specific cost of construction ${ }^{11}$ : in $\$$ per (installed) $\mathrm{kW}_{\mathrm{e}}$. - The specific cost of fuel: in $\$$ per (produced) $M W_{\mathrm{e}} \mathrm{h}$.

- The specific cost of O\&M: in $\$$ per (produced) $M_{\mathrm{e}} \mathrm{h}$.

- The specific cost of decommissioning: in $\$$ per (installed) $\mathrm{kW}_{\mathrm{e}}$.

Once minimal annual cash in (ci) is evaluated, the cost of electricity is deduced by dividing ci by the annual electricity production volume ${ }^{12}\left(P_{\text {Elec, } 1 Y}\right)$ :

$$
c_{\mathrm{kW}} \mathrm{h}=\frac{\mathrm{ci}}{P_{\text {Elec }, 1 Y}},
$$

$c_{\mathrm{kW}}$ h , cost of electricity; $P_{\mathrm{Elec}, 1 Y}$, annual electricity production volume $\left(\mathrm{kW}_{\mathrm{e}} \mathrm{h}\right)$. (\$ per $\left.\mathrm{kW}_{\mathrm{e}} \mathrm{h}\right)$.

A numerical example of electricity cost calculation for a $1000 \mathrm{MW}_{\mathrm{e}} \mathrm{PWR}$ is provided in Table 8. The results show good agreement with the evaluation reported in OECD' 2010 Projected Costs of Generating Electricity [9].

\subsection{Dual-purpose plant}

The traditional method (Method 1) for evaluating the cost of process heat consists in multiplying the cost of electricity, as calculated for SPP, by the expected decrease in electricity production.

Consider the $1000 \mathrm{MW}_{\mathrm{e}}$ PWR example of Table 8 . According to the thermodynamic model described in the previous section, the reactor can produce up to $1730 \mathrm{MW}_{\text {th }}$ of process heat at $80^{\circ} \mathrm{C}$. Each $\mathrm{MW}_{\mathrm{th}} \mathrm{h}$ supplied to the

\footnotetext{
${ }^{10}$ All expenses are considered "overnight", i.e. interest free. Inflation (fuel cost escalation in particular) is not taken into account

${ }^{11}$ Owner's, construction and contingency costs.

12 The annual electricity production volume is evaluated from the reference electric power generation capacity assuming a constant average availability of the plant.
}

Table 8. SPP (PWR $2748 \mathrm{MW}_{\mathrm{th}} \rightarrow 1000 \mathrm{MW}_{\mathrm{e}}$ ): electricity cost.

Reference core thermal power $\left(\mathrm{MW}_{\text {th }}\right) \quad 2748$

Reference electric power generation capacity 1000

$\left(\mathrm{MW}_{\mathrm{e}}\right)$

Specific construction cost $\left(\$\right.$ per installed $\mathrm{kW}_{\mathrm{e}} \quad 4101.51^{\mathrm{a}}$

(electric power))

Specific fuel cost ( $\$$ per produced $\mathrm{MW}_{\mathrm{e}} \mathrm{h}$

(electric power))

Specific O\&M cost $\left(\$\right.$ per produced $\mathrm{MW}_{\mathrm{e}} \mathrm{h} \quad 14.74^{\mathrm{a}}$

(electric power))

Specific decommissioning cost $\left(\$\right.$ per installed $820.30^{\mathrm{b}}$

$\mathrm{kW}_{\mathrm{e}}$ (electric power))

Length of the construction period (years) $\quad 7^{\mathrm{a}}$

Economic lifetime of the plant (years) $\quad 60^{\mathrm{a}}$

Average availability of the plant (\%) $85^{\mathrm{a}}$

Length of the decommissioning period (years) 5

Discount rate (\%) 5

Cost of electricity $\left(10^{-2} \$\right.$ per $\left.\mathrm{kW}_{\mathrm{e}} \mathrm{h}\right)$

Percentage allocated to construction (\%) $\quad 58.15 \%$

Percentage allocated to fuel $(\%) \quad 16.04 \%$

Percentage allocated to O\&M (\%) $\quad 25.34 \%$

Percentage allocated to decommissioning (\%) $0.46 \%$

a Values suggested in the OECD' 2010 Projected Costs of Generating Electricity [9, p. 103].

b $20 \%$ of the specific construction cost.

external process at this temperature will cause the reactor's net power output to decrease by $123 \mathrm{~kW}_{\mathrm{e}} \mathrm{h}$ (W-cost of heat). With a cost of electricity of 5.82 cents per $\mathrm{kW}_{\mathrm{e}} \mathrm{h}$, the cost of heat would be equal to $7.15 \$$ per $\mathrm{MW}_{\mathrm{th}} \mathrm{h}(0.715$ cents per $\mathrm{kW}_{\mathrm{th}} \mathrm{h}$ ).

An alternative method of evaluating the cost of heat (Method 2) consists of considering a modified reactor design $\left(\mathrm{DPP}_{2}\right.$, cf. Tabs. 6 and 7 ) offering higher core power output compared to SPP. Such plant would generate the 


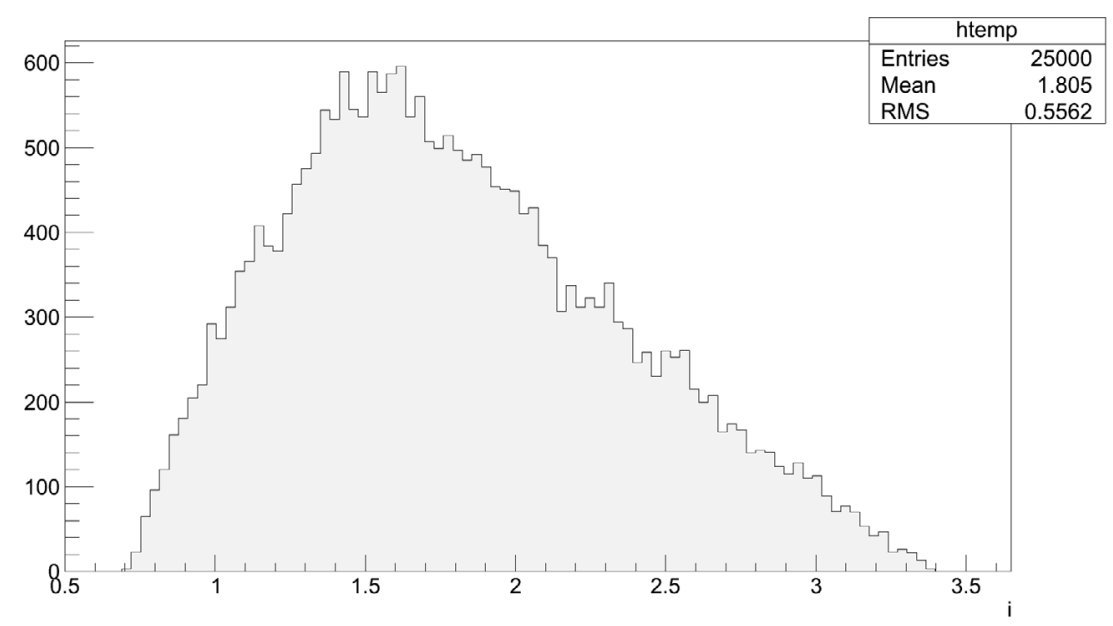

Fig. 6. Number of entries (vertical axis) for which i equals a certain value (horizontal axis).

same amount of electricity as SPP (1000 MWe while meeting the demand of the external process in terms of thermal power $\left(1000 \mathrm{MW}_{\text {th }}\right.$ at $\left.80^{\circ} \mathrm{C}\right)$.

At $80^{\circ} \mathrm{C}$, the Q-cost of heat is equal to $338 \mathrm{kWh}_{\text {th }}$ per $\mathrm{MW}_{\mathrm{th}}$. This means that, in order to produce $1000 \mathrm{MW}_{\mathrm{th}}$ of process heat at $80^{\circ} \mathrm{C}$, without affecting the electric power generation capacity, the core power has to be raised from 2748 to $3086 \mathrm{MW}_{\text {th }}(+12.3 \%)$.

The effect of increasing core power on construction costs can be estimated based on the formula:

$$
\frac{\operatorname{cost}_{\mathrm{DPP}}}{\text { cost }_{\mathrm{SPP}}}=0.75+0.25 \times\left(\frac{\dot{Q}_{\mathrm{Core}, \mathrm{DPP}}}{\dot{Q}_{\mathrm{Core}, \mathrm{SPP}}}\right)^{0.6} .
$$

Equation (11) assumes that:

- Nuclear Island represents roughly $x=25 \%$ of the costs.

- The cost relative to Nuclear Island:

- Depends on core power exclusively.

- Can be scaled-up applying a capital scaling function ${ }^{13}$ with a scaling exponent equal to $n=0.6 .^{14}$

- The remaining $75 \%$ of the costs depend solely on the plant power generation capacity (which is the same for both SPP and DPP).

The Single-Purpose $1000 \mathrm{MW}_{\mathrm{e}}$ PWR example of Table 8 costs 4.102 billion $\$$ to construct. Adding $338 \mathrm{MW}_{\text {th }}$ to core power would increase this cost by $i=1.8 \%$. If $x$ and $n$-which are rather uncertain-are uniformly distributed, in $[15-35]$ (\%) for $x$, and in [0.4-0.8] for $n, i$ would have the distribution ${ }^{15}$ shown in Figure 6 (mean value for cost increase: $1.8 \%$, standard deviation: $0.56 \%$ ). A cost increase of $3.5 \%$ appears to be an upper limit.

\footnotetext{
${ }^{13}$ Capital cost scaling functions are often used to account for economies of scale (as the nuclear island gets larger in size, it gets progressively cheaper to add additional capacity). Examples from the power generation industry are provided in [14].

${ }^{14}$ When $n$ is unknown, a value of 0.6 is generally assumed (rule of six-tenths).

${ }^{15}$ Figure 6 was obtained after (Latin Hypercube) sampling of two inputs, carried out using CEA's open source software URANIE [15].
}

Increasing core power has also an impact on fuel costs. A simple way to take it into account is to apply a correction factor $(f)$ to $\mathrm{SPP}^{\prime}$ s specific fuel cost (Eq. (12)). Although $\mathrm{SPP}$ and $\mathrm{DPP}_{2}$ have the same power generation capacity, the annual electricity production volume can differ between the two plants depending on the availability of $\mathrm{DPP}_{2}$ vs. SPP. If we assume a $1 \%$ decrease in availability for $\mathrm{DPP}_{2}$ compared to SPP (84\% for $\mathrm{DPP}_{2}$ vs. $85 \%$ for $\mathrm{SPP})$, the increase in fuel costs would be equal to $12.31 \%$.

$$
f=\frac{P_{\text {Elec }, 1 Y, \mathrm{SPP}}}{P_{\mathrm{Elec}, 1 Y, \mathrm{DPP}}} \times \frac{P_{\mathrm{Core}, 1 Y, \mathrm{DPP}}}{P_{\mathrm{Core}, 1 Y, \mathrm{SPP}}},
$$

$P_{\text {Elec, } 1 Y, \mathrm{SPP}}$, annual electricity production volume, SPP $\left(\mathrm{kW}_{\mathrm{e}} \mathrm{h}\right) ; P_{\text {Elec,1 } Y \text {,DPP }}$, annual electricity production volume, DPP $\left(\mathrm{kW}_{\mathrm{e}} \mathrm{h}\right) ; \quad P_{\mathrm{Core}, 1 Y, \mathrm{SPP}}$, annual production volume, thermal power, SG, SPP $\left(\mathrm{kW}_{\mathrm{th}} \mathrm{h}\right) ; P_{\text {Core, } 1 Y \text {.DPP, }}$ annual production volume, thermal power, SG, DPP $(\mathrm{kW}$ th $\mathrm{h})$.

The rise in O\&M expenses is expected to be less sensitive to the increase in core power compared to fuel costs. The correction factor $\left(f^{\prime}\right)$, applicable to SPP's specific O\&M cost, is assumed to be the following:

$$
f^{\prime}=\frac{1+f}{2}
$$

Table 9 provides a preliminary economic evaluation of $\mathrm{DPP}_{2}$ vs. SPP. The cost of heat reported in this table is calculated following the steps listed below:

- The-minimal annual cash in required to have a positive $\mathrm{NPV}-\left(\mathrm{ci}_{\mathrm{DPP}}\right)$ is calculated for $\mathrm{DPP}_{2}$.

- We assume that all electricity generated by $\mathrm{DPP}_{2}$ is sold at 5.82 cents per $\mathrm{kW}_{\mathrm{e}} \mathrm{h}$-i.e. the cost of electricity as produced by SPP $\left(c_{\mathrm{kWeh}, \mathrm{SPP}}\right)$.

- We use the difference between, the - minimal annual cash in required to have a positive NPV-and, the-annual revenue generated from the sale of electricity - as a basis for evaluating the cost of heat (Eq. (14)).

$$
c_{\mathrm{kW}_{\mathrm{th}} \mathrm{h}, \mathrm{DPP}}=\frac{\mathrm{ci}_{\mathrm{DPP}}-c_{\mathrm{kW}_{\mathrm{e}, \mathrm{SPP}}} \times P_{\mathrm{Elec}, 1 Y, \mathrm{DPP}}}{P_{\text {Heat }, 1 Y, \mathrm{DPP}}} .
$$


Table 9. $\mathrm{DPP}_{2}\left(\mathrm{PWR} 3086 \mathrm{MW}_{\mathrm{th}} \rightarrow 1000 \mathrm{MW}_{\mathrm{e}}+1000 \mathrm{MW}_{\text {th }}\right.$ at $\left.80^{\circ} \mathrm{C}\right)$ : electricity and heat costs.

\begin{tabular}{|c|c|c|}
\hline & SPP & $\mathrm{DPP}_{2}$ \\
\hline Reference core thermal power $\left(\mathrm{MW}_{\mathrm{th}}\right)$ & 2748 & $3086(+12.3 \%)$ \\
\hline Reference electric power generation capacity $\left(\mathrm{MW}_{\mathrm{e}}\right)$ & 1000 & 1000 \\
\hline Reference process heat generation capacity $\left(\mathrm{MW}_{\text {th }}\right.$ at $\left.80^{\circ} \mathrm{C}\right)$ & - & 1000 \\
\hline Specific construction cost ( $\$$ per installed $\mathrm{kW}_{\mathrm{e}}($ electric power $)$ ) & 4101.51 & $4175.451(+1.8 \%)$ \\
\hline Specific fuel cost ( $\$$ per produced $\mathrm{MW}_{\mathrm{e}} \mathrm{h}$ (electric power)) & 9.33 & $10.478(+12.31 \%)$ \\
\hline Specific O\&M cost ( $\$$ per produced $\mathrm{MW}_{\mathrm{e}} \mathrm{h}$ (electric power)) & 14.74 & $15.647(+6.15 \%)$ \\
\hline Specific decommissioning cost ( $\$$ per installed $\mathrm{kW}_{\mathrm{e}}$ (electric power $)$ ) & 820.30 & $835.090(+1.8 \%)$ \\
\hline Length of the construction period (years) & 7 & 7 \\
\hline Economic lifetime of the plant (years) & 60 & 60 \\
\hline Average availability of the plant (\%) & 85 & 84 ( -1 point $)$ \\
\hline Length of the decommissioning period (years) & 5 & 5 \\
\hline Discount rate $(\%)$ & 5 & 5 \\
\hline Minimal annual cash in required to have a positive NPV (million $\$$ ) & 433.378 & $450.979(+17.601)$ \\
\hline Cost of electricity $\left(10^{-2} \$\right.$ per $\left.\mathrm{kW}_{\mathrm{e}} \mathrm{h}\right)$ & 5.816 & \\
\hline Cost of heat $\left(10^{-2} \$\right.$ per $\mathrm{kW}_{\text {th }} \mathrm{h}$ at $\left.80^{\circ} \mathrm{C}\right)$ & - & 0.308 \\
\hline Cost of heat (DPP) to cost of electricity (SPP) & & $5.30 \%$ \\
\hline
\end{tabular}

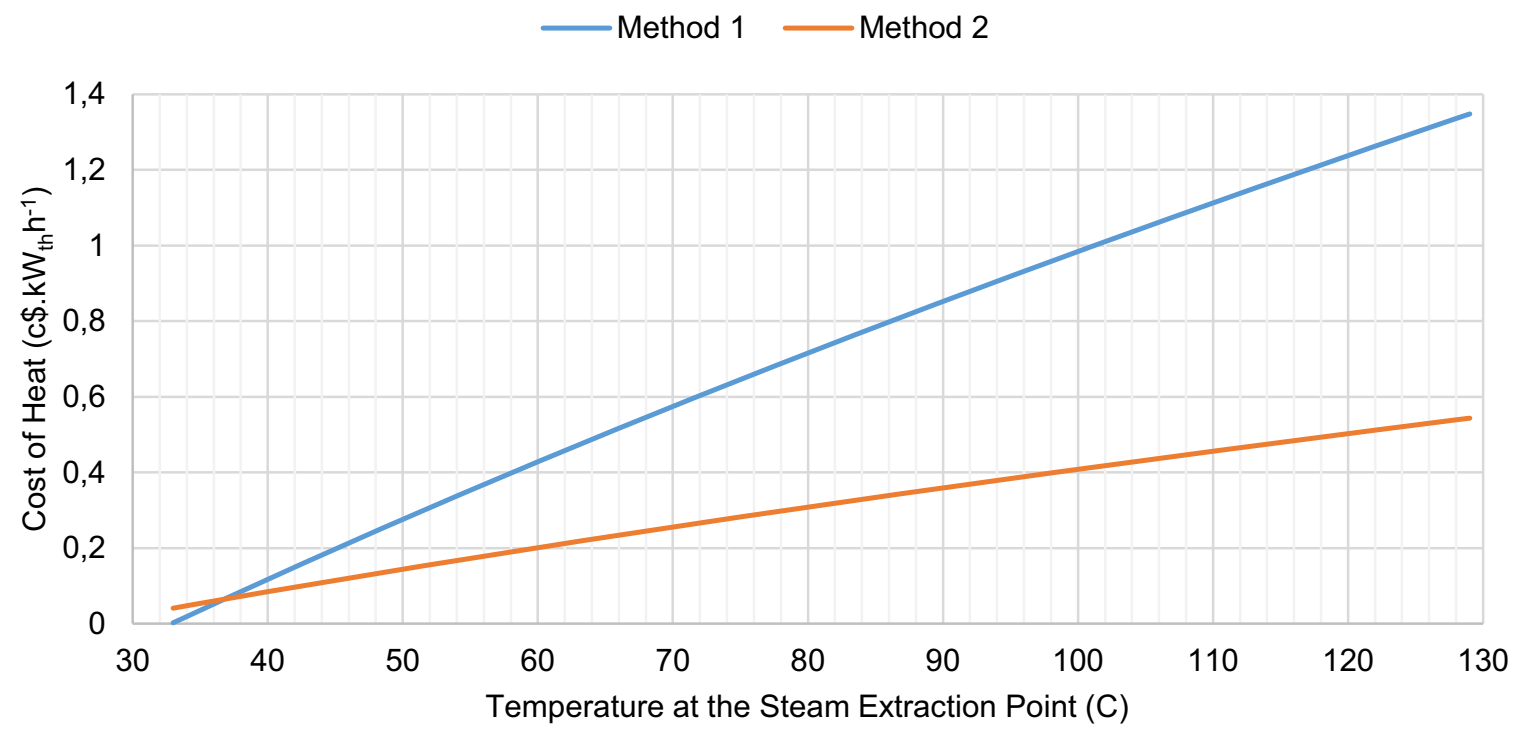

Fig. 7. Cost of heat vs. temperature at the steam extraction point.

The cost of heat, as calculated by this method (Method 2 ), is equal to 0.308 cent per $\mathrm{kW}_{\text {th }} \mathrm{h}\left(80^{\circ} \mathrm{C}\right)$, which represents $5.30 \%$ of the cost of electricity produced by SPP. This cost is $57 \%$ percent lower than the cost calculated by Method 1. Figure 7 shows how the cost varies with the level of temperature required by the external process.

At $75^{\circ} \mathrm{C}$, each $\mathrm{kW}_{\text {th }} \mathrm{h}$ of thermal power supplied to the process costs $0.282 \mathrm{c} \$$. At $100^{\circ} \mathrm{C}$, the cost rises to $0.408 \mathrm{c} \$ \mathrm{~kW}_{\mathrm{th}} \mathrm{h}^{-1}(\times 1.45)$, and at $125^{\circ} \mathrm{C}$ it reaches $0.525 \mathrm{c} \$ \mathrm{~kW}_{\mathrm{th}} \mathrm{h}^{-1}(\times 1.86)$. These costs, estimated based on Method 2, represent 4.9-9.0\% of the cost of electricity, depending on the steam extraction temperature (Fig. 8).
The ratio-cost of heat to cost of electricity - will be referred to as the E-cost of heat (ECH). ECH is subject to the size effect (Fig. 9). It is also sensitive to availability of the cogeneration plant, as shown in Figure 10.

Method 2 provides an alternative approach to converting $\mathrm{MW}_{\mathrm{th}}$ to $\mathrm{MW}_{\mathrm{e}}$, considering the benefits of cogeneration - it allocates CAPEX and OPEX to the two byproducts - but also, the constraints introduced by the integrated system-higher expenses, extended construction period, lower availability, etc.

In the next section, we will use this method to compare two nuclear-powered integrated water and power plants, based on either, multi-effect distillation, or, seawater RO. 


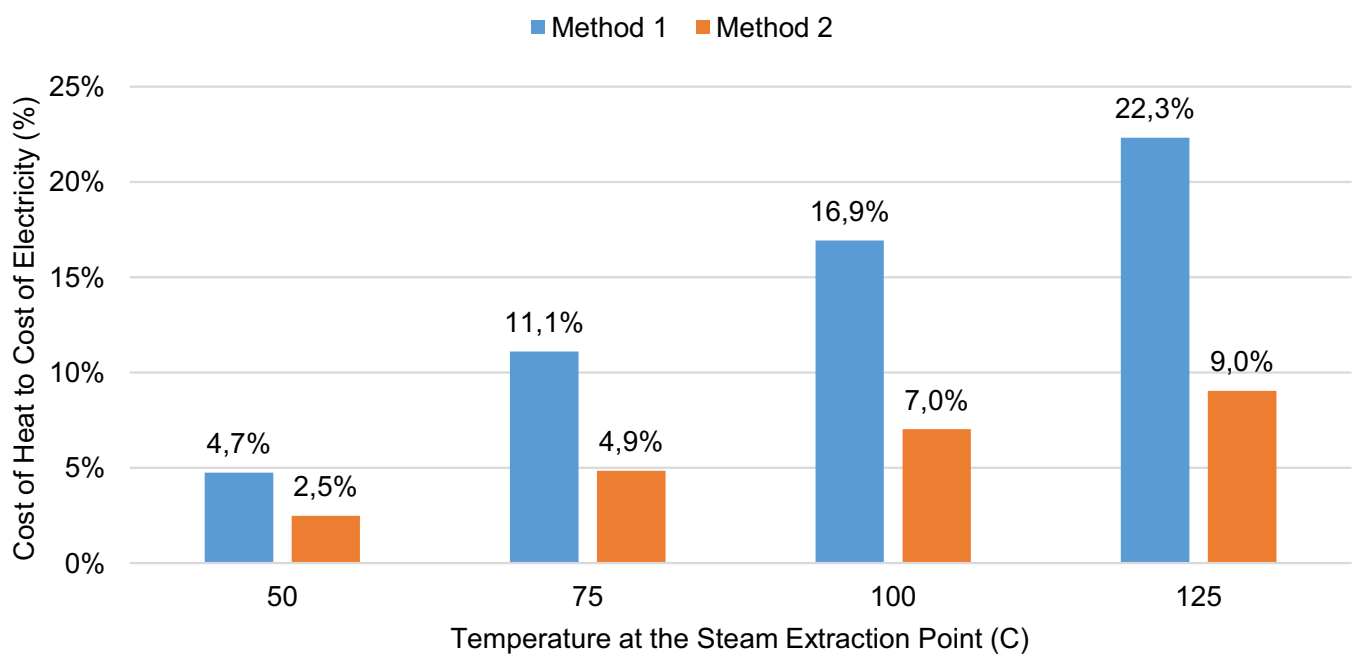

Fig. 8. Cost of heat to cost of electricity vs. temperature at the steam extraction point.

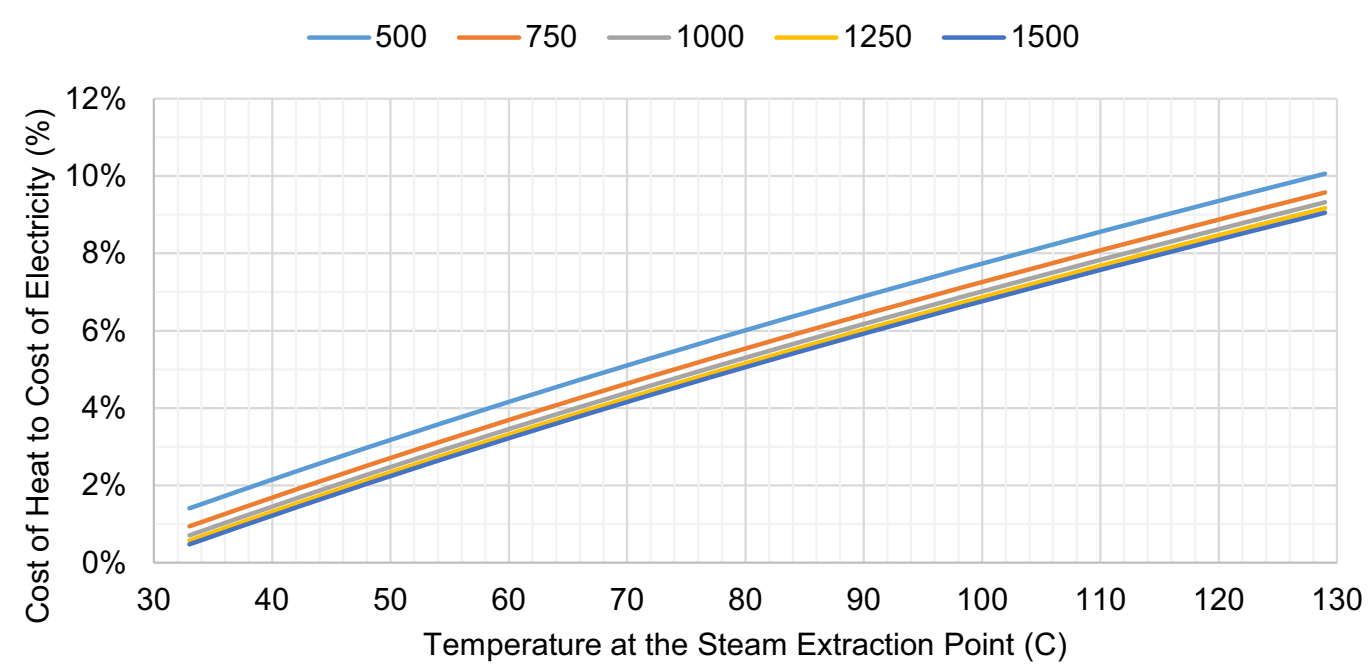

Fig. 9. Cost of heat to cost of electricity vs. temperature at the steam extraction point (Method 2) for different values of process thermal power $\left(\mathrm{MW}_{\mathrm{th}}\right)$.

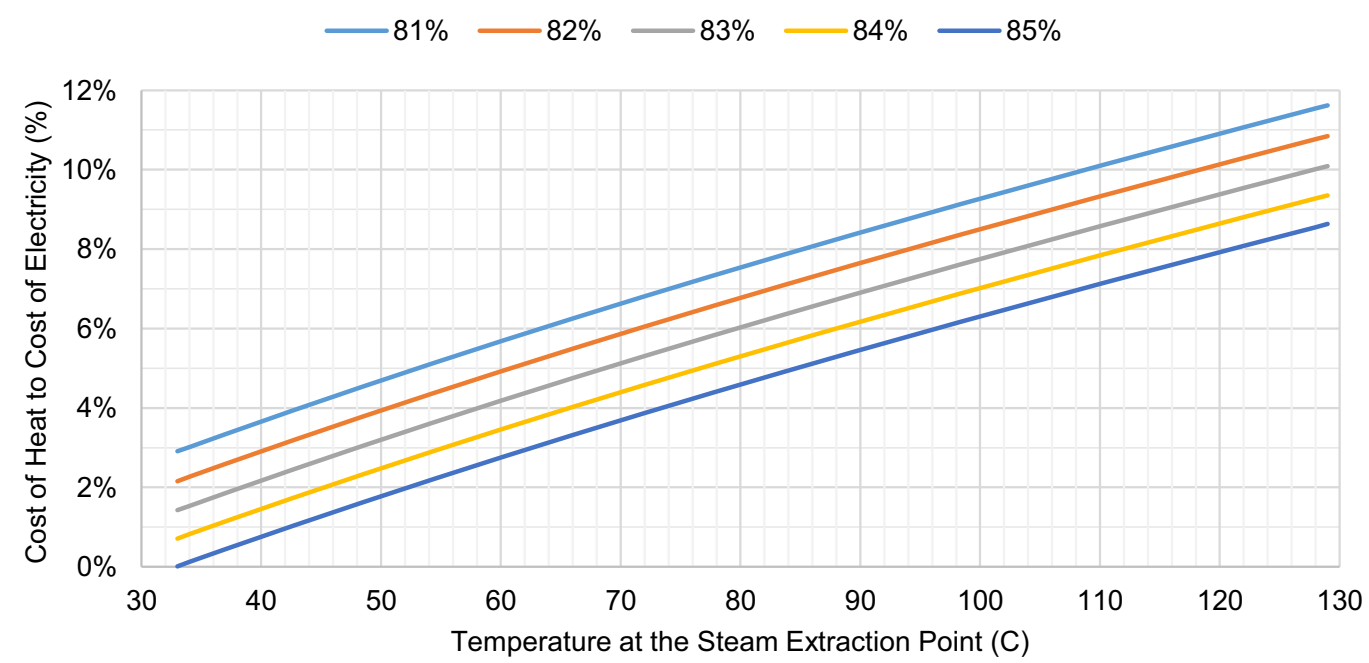

Fig. 10. Cost of heat to cost of electricity vs. temperature at the steam extraction point (Method 2) for different values of $\left(\mathrm{DPP}_{2}\right)$ availability. 


\section{Impact on the cost of desalination}

\subsection{MED process performance model}

The MED process performance model aims at evaluating its specific thermal power consumption, in $\mathrm{kW}_{\text {th }} \mathrm{h} \mathrm{m}^{-3}$ for fresh water produced by the plant. Based on the simplified approach already implemented in the DEEP Code [16], the model follows the three steps described below:

- First, the number of MED stages is determined (Eq. (15)) based on:

- The temperatures at the first stage (top brine temperature) and the final condenser.

- The average temperature drop between stages.

$$
N_{\text {Stages }}=\operatorname{int}\left(\frac{T_{\max }-T_{\min }}{\Delta T_{\text {Stages }}}\right),
$$

$N_{\text {Stages}}$, number of stages; int (function), round down real numbers to the nearest integer; $T_{\max }$, top brine temperature, $\left({ }^{\circ} \mathrm{C}\right) ; T_{\min }$, temperature at the final condenser, $\left({ }^{\circ} \mathrm{C}\right)$; $\Delta T_{\text {Stages }}$, average temperature drop between stages, $\left({ }^{\circ} \mathrm{C}\right)$.

Table 10. Example of MED process performance calculation (1).

Top brine temperature $\left({ }^{\circ} \mathrm{C}\right)$

Temperature at the final condenser $\left({ }^{\circ} \mathrm{C}\right)$

Average temperature drop between stages $\left({ }^{\circ} \mathrm{C}\right)$

Number of stages $(-)$

GOR to number of stages

GOR (-)

Pinch point temperature difference, first effect $\left({ }^{\circ} \mathrm{C}\right) \quad 5$

Steam supply temperature $\left({ }^{\circ} \mathrm{C}\right)$

Specific heat consumption $\left(\mathrm{kWh}_{\mathrm{th}} \mathrm{m}^{-3}\right)$
- The gain output ratio (GOR) (kilograms of fresh water produced per kilogram of steam supplied to the process) is then estimated based on an average effect efficiency of 0.8 :

$$
\mathrm{GOR}=0.8 \times \mathrm{NS} .
$$

- The specific power consumption $\left(\mathrm{kW}_{\mathrm{th}} \mathrm{h} \mathrm{m}{ }^{-3}\right)$ is finally deduced:

$$
\mathrm{SHC}=\frac{L}{3.6 \times \mathrm{GOR}},
$$

$L$, latent heat at steam supply temperature, $\left(\mathrm{kJ} \mathrm{kg}^{-1}\right)$.

A numerical example of MED process performance calculation is provided in Table 10.

The specific thermal power consumption evaluated by this model is sensitive to both, the temperature difference between MED effects, and, the stage average efficiency, as illustrated by Figures 11 and 12 .

\subsection{MED equivalent specific electric power consumption}

The calculations, reported in this paragraph, are based on the following assumptions:

- MED model inputs are basically those listed in Table 10. Only the top brine-and steam supply-temperatures vary.

- A (pinch point temperature) difference of $5^{\circ} \mathrm{C}$ between MED's steam supply temperature and the temperature at the steam extraction point $\left(T_{\mathrm{SteamEx}}\right.$, power conversion system).

- Conversion of MED specific power thermal consumption to an electric equivalent is performed based on either:

- the W-cost of heat (cf. Sect. 2.3) (Method 1), or,

- the - cost of heat to cost of electricity - ratio (ECH) as calculated by Method 2 (cf. Sect. 3.2).

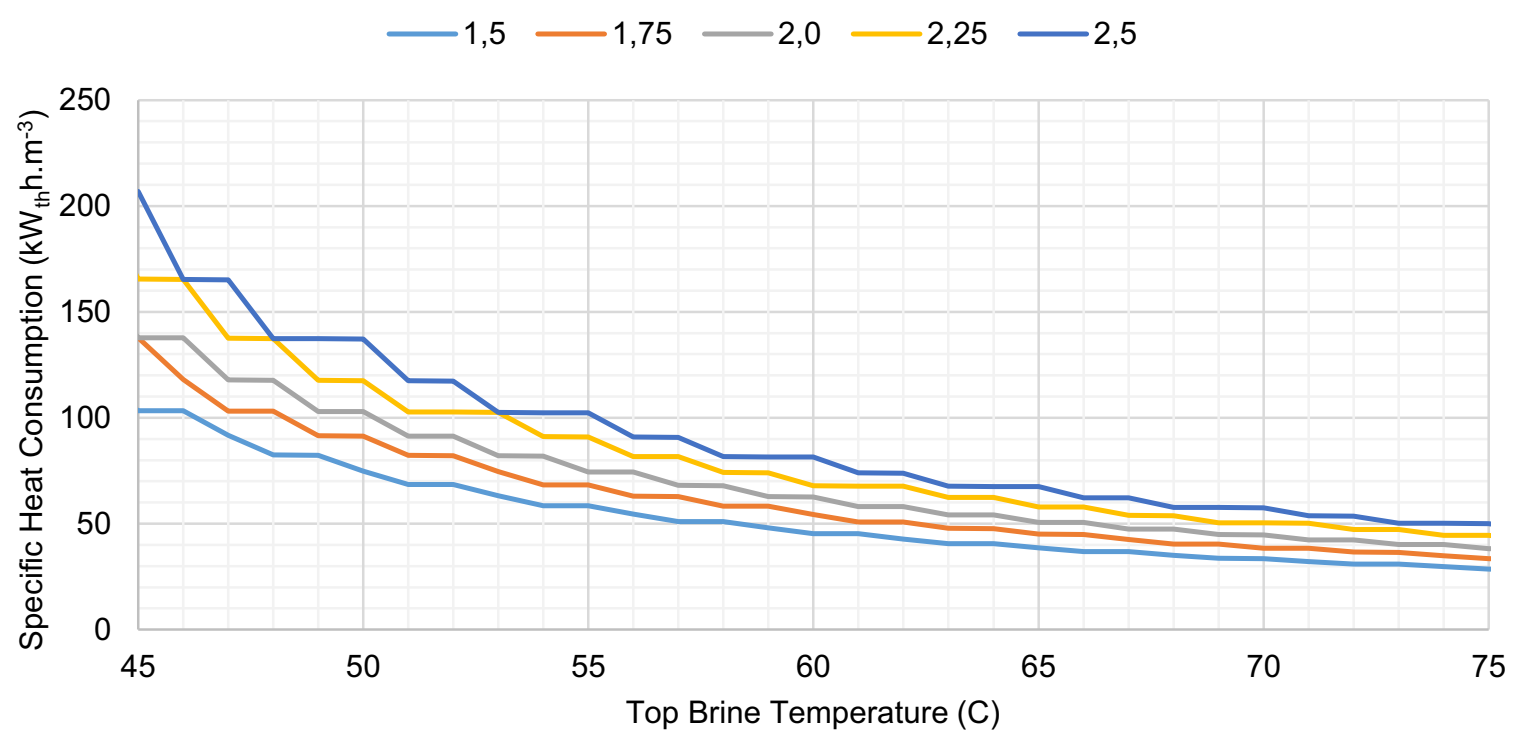

Fig. 11. MED specific thermal power consumption vs. top brine temperature. 1.5, 1.75, 2.0, 2.25, 2.5: average temperature drop between stages $\left({ }^{\circ} \mathrm{C}\right)$. 


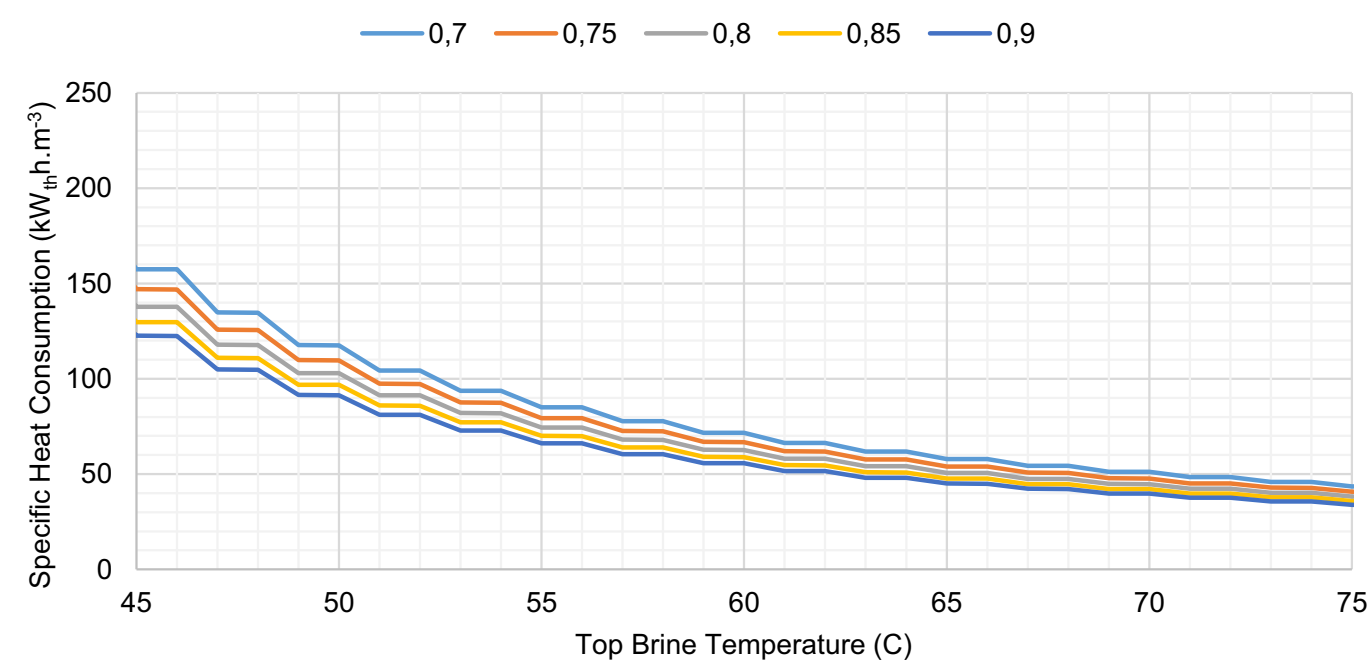

Fig. 12. MED specific thermal power consumption vs. top brine temperature. $0.7,0.75,0.8,0.85,0.9$ : GOR to number of stages.

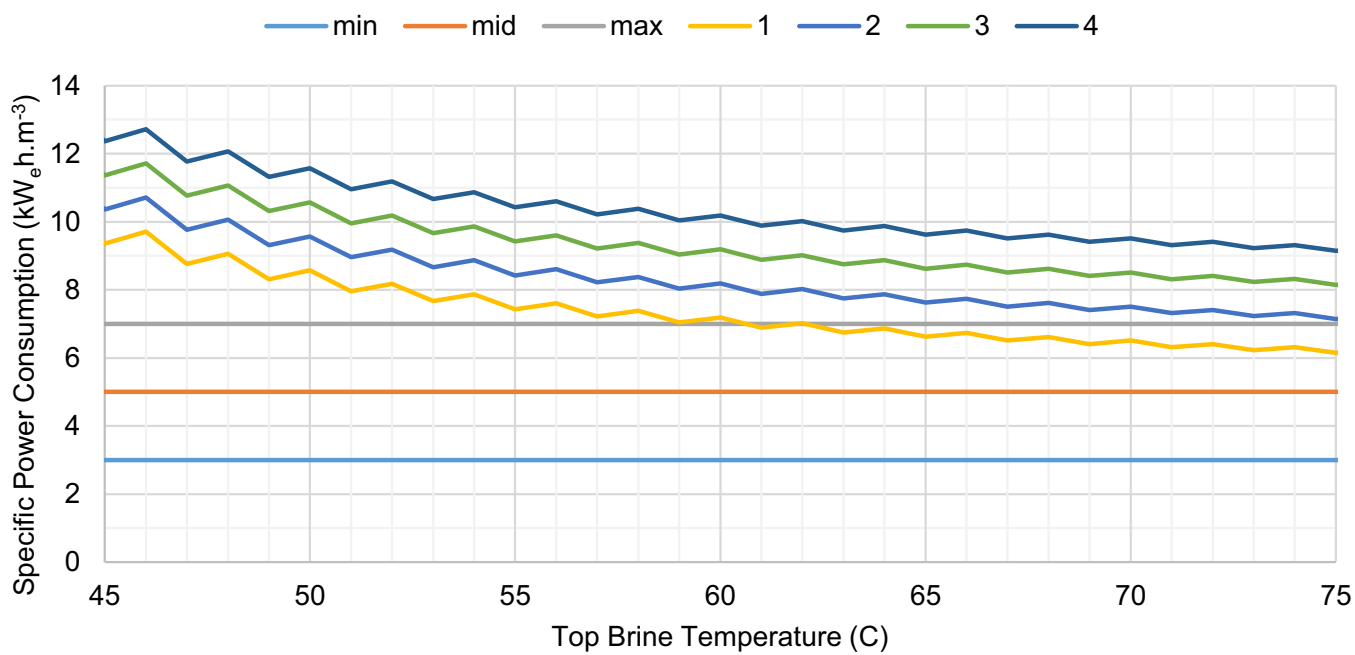

Fig. 13. MED energy cost vs. top brine temperature. Based on Method 1. 1, 2, 3, 4: MED specific electric consumption equal to 1, 2, 3 and $4 \mathrm{~kW}_{\mathrm{e}} \mathrm{m}^{-3}$ respectively. min, mid, and max: minimal, medium and maximal specific electric consumption of the SWRO process as reported in literature.

Figure 13 shows how MED's equivalent electric power consumption ${ }^{16}$ varies with the top brine temperature (TBT). Conversion from $\mathrm{W}_{\mathrm{th}}$ to $\mathrm{W}_{\mathrm{e}}$ is based, in this case, on the $\mathrm{W}$-cost of heat (WCH).

The power required to produce a cubic meter of fresh water, as calculated by Method 1, is higher for MED than for SWRO, except for processes operating at a TBT higher than 60 , with a specific electric consumption lower than $1 \mathrm{~kW}_{\mathrm{e}} \mathrm{m}^{-3}$, for which the equivalent electric power consumption is in the range $6-7 \mathrm{~kW}_{\mathrm{e}} \mathrm{m}^{-3}$.

If the - cost of heat to cost of electricity - ratio (ECH), as calculated by Method 2, is used as a basis for converting $\mathrm{W}_{\text {th }}$ to $\mathrm{W}_{\mathrm{e}}, \mathrm{MED}$ 's efficiency, in terms of energy utilization, is globally improved, as illustrated by Figure 14 .

\footnotetext{
${ }^{16}$ Electric equivalent of the thermal power supplied by the nuclear reactor, plus, electric power consumption internal to the process.
}

Figure 14 shows that, for specific consumptions in the range $[1-4] \mathrm{kW}_{\mathrm{e}} \mathrm{m}^{-3}$, MED's equivalent electric power consumption varies between 3 and $6 \mathrm{~kW}_{\mathrm{e}} \mathrm{m}^{-3}$, matching the range of the $\mathrm{RO}$ specific electric consumption as reported in literature.

MED's equivalent electric power consumption can be further reduced by, raising the TBT, ${ }^{17}$ decreasing the average temperature drop between MED stages, ${ }^{18}$ or, increasing MED effects' efficiency ${ }^{19}$ (GOR to number of stages), as illustrated by the example provided in Table 11 .

${ }^{17}$ Raising the TBT exposes the plant to severe corrosion and scaling problems. In recent years, many of these problems have been solved thanks to improvements in materials and antiscalants.

${ }^{18}$ Reducing the temperature difference requires larger heat transfer surfaces.

${ }^{19}$ Effect efficiency can be improved by reducing thermal losses. 


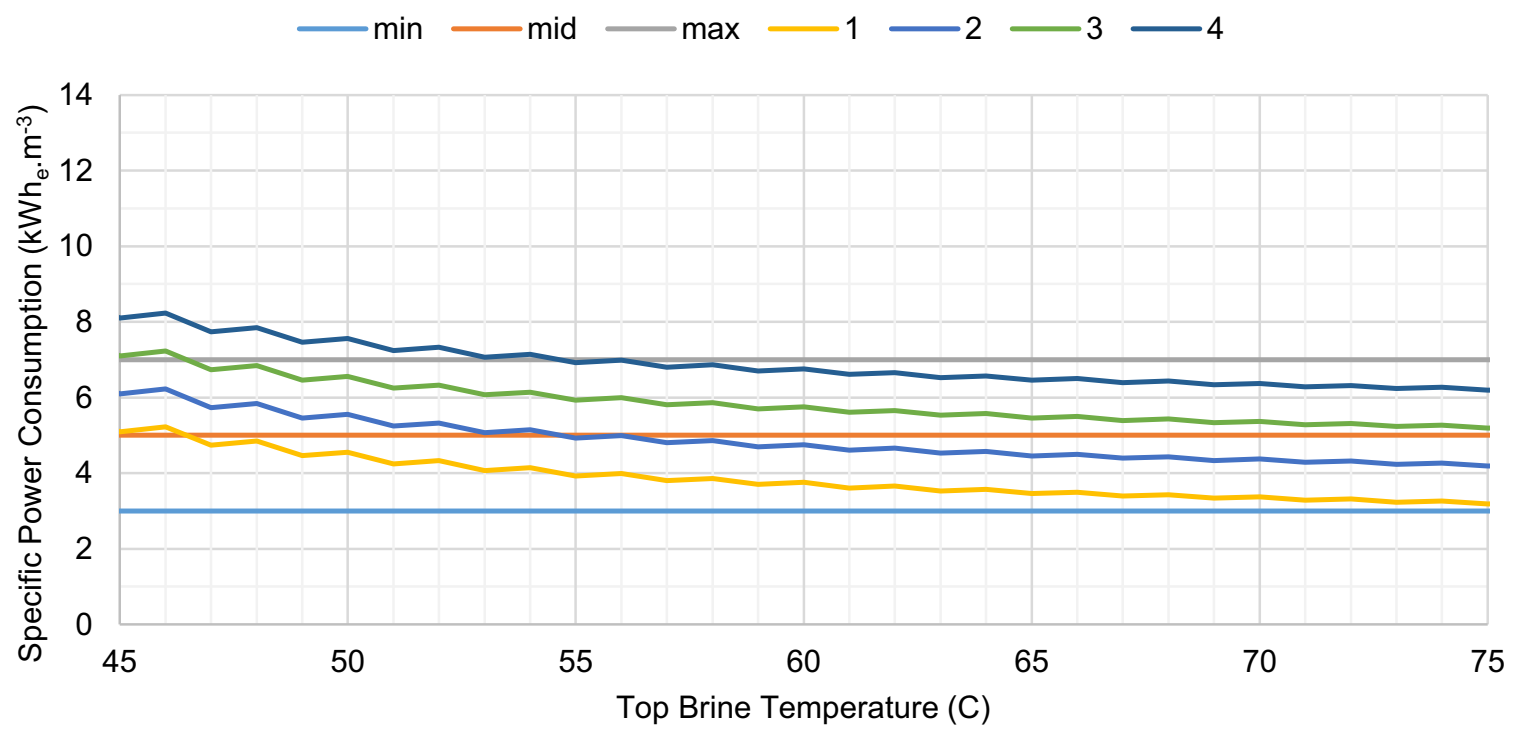

Fig. 14. MED energy cost vs. top brine temperature. Based on Method 2. 1, 2, 3, 4: MED specific electric consumption equal to $1,2,3$ and $4 \mathrm{~kW}_{\mathrm{e}} \mathrm{m}^{-3}$ respectively. min, mid, and max: minimal, medium and maximal specific electric consumption of the SWRO process as reported in literature.

Table 11. Example of MED process performance calculation (2).

Top brine temperature $\left({ }^{\circ} \mathrm{C}\right)$ 75

Temperature at the final condenser $\left({ }^{\circ} \mathrm{C}\right)$

Average temperature drop between stages $\left({ }^{\circ} \mathrm{C}\right)$

Number of stages $(-)$

GOR to number of stages

GOR (-)

Pinch point temperature difference, first effect $\left({ }^{\circ} \mathrm{C}\right)$

Steam supply temperature $\left({ }^{\circ} \mathrm{C}\right)$

Specific heat consumption $\left(\mathrm{kWh}_{\mathrm{th}} \mathrm{m}^{-3}\right)$

Equivalent electric power consumption $\left(\mathrm{kW}_{\mathrm{e}} \mathrm{m}^{-3}\right)$ - Basis: $1 \mathrm{~kW}_{\mathrm{e}} \mathrm{m}^{-3}$

Equivalent electric power consumption $\left(\mathrm{kW}_{\mathrm{e}} \mathrm{m}^{-3}\right)$ - Basis: $2 \mathrm{~kW}_{\mathrm{e}} \mathrm{m}^{-3}$

a MED manufacturers claim a GOR of 10-16 in working units and up to 30 in designed prototypes [2].

\section{Conclusion}

Process heat has an energetic and an economic cost that affects the cost of desalination. The exploratory study, described in this paper, attempted to evaluate these costs based on simplified models.

The power conversion system model provided a basis for assessing the "W-cost of heat" (WCH) - number of $\mathrm{kW}_{\mathrm{e}}$ of "missed electricity production" per $\mathrm{MW}_{\text {th }}$ of process power - and the "Q-cost of heat" $(\mathrm{QCH})$ - number of $\mathrm{kW}_{\text {th }}$ of additional core power (required to keep a constant level of electricity production) per $\mathrm{MW}_{\mathrm{th}}$.
The economic model helped evaluate the "E-cost of heat" (ECH), defined as the ratio-cost of heat to cost of electricity - taking into account cogeneration's benefits and constraints.

The three costs-WCH, QCH, and $\mathrm{ECH}-$ depend primarily on the level of temperature required by the process. ECH also depends on the economic model's inputs.

This work confirms two conclusions from an earlier study by Rognoni et al. [8]:

- Evaluating the heat cost on the basis of WCH (and the cost of electricity generated by a single-purpose power plant) leads to higher energy costs for MED compared to SWRO. 
- A rigorous techno-economic approach, duly considering the benefits of cogeneration, results in lower heat costs, and comparable equivalent electric power consumptions between MED and SWRO.

Energy is an important contributor to the cost of desalted water-a contributor among many others: construction, O\&M, chemicals, insurance, labor ... - - Evaluating the cost of desalted water should take into account all the expenses related to the project, including the investments needed to construct (or extend) water transfer and supply networks (IWPPs are generally located far from urban and industrial areas).

Water desalination plants produce huge amounts of reject brine. This brine can be turned into salt [17] or used to convert $\mathrm{CO}_{2}$ into useful and reusable products such as sodium bicarbonate[18]. These processes-still under development - can potentially improve the economics of seawater desalination while minimizing the impact of brine discharge on the environment.

To identify the most appropriate reactor-process combination for a given site, case-specific evaluations have to be performed, considering the precise characteristics of the power generation system, the reactor to process heat transfer loop, the seawater desalination unit, and the water transport system. Other important factors have also to be considered such as the final use of the product, the quality of the feed, the-intake, pretreatment, post-treatment and brine reject - structures, and the variability of the demand for power and water.

\section{Abbreviations}

CAPEX capital expenditures

DEEP desalination economic evaluation program (Software)

$\begin{array}{ll}\text { DPP } & \text { dual-purpose plant } \\ \text { ECH } & \text { E-cost of heat } \\ \text { ED } & \text { electrodialysis } \\ \text { GOR } & \text { gain output ratio } \\ \text { HPT } & \text { high pressure turbine } \\ \text { IAEA } & \text { international atomic energy agency } \\ \text { ICV } & \text { interconnected control volumes (software) } \\ \text { IWPP } & \text { integrated water and power plant } \\ \text { LPT } & \text { low pressure turbine } \\ \text { MED } & \text { multi-effect evaporation } \\ \text { MSF } & \text { multi-stage flash } \\ \text { NPV } & \text { net present value } \\ \text { O\&M } & \text { operation and maintenance } \\ \text { OPEX } & \text { operating expenditures } \\ \text { PCS } & \text { power conversion system } \\ \text { PWR } & \text { pressurized water reactor } \\ \text { QCH } & \text { Q-cost of heat } \\ \text { RO } & \text { reverse osmosis } \\ \text { SG } & \text { steam generator } \\ \text { SPP } & \text { single-purpose plant } \\ \text { SteamEx } & \text { steam extraction point } \\ \text { SWRO } & \text { seawater reverse osmosis } \\ \text { TBT } & \text { top brine temperature } \\ \text { WCH } & \text { W-cost of heat }\end{array}$

\section{Appendix}

Cost of heat vs. temperature at the extraction point.

\begin{tabular}{|c|c|c|c|c|c|c|c|}
\hline$T$ & WCH & $\mathrm{QCH}$ & $\mathrm{ECH}$ & $T$ & WCH & $\mathrm{QCH}$ & $\mathrm{ECH}$ \\
\hline 33 & 0 & 1 & 7 & 81 & 125 & 345 & 54 \\
\hline 34 & 3 & 9 & 8 & 82 & 128 & 351 & 55 \\
\hline 35 & 6 & 17 & 9 & 83 & 130 & 358 & 56 \\
\hline 36 & 9 & 25 & 10 & 84 & 133 & 364 & 57 \\
\hline 37 & 12 & 32 & 11 & 85 & 135 & 371 & 57 \\
\hline 38 & 15 & 40 & 12 & 86 & 137 & 377 & 58 \\
\hline 39 & 17 & 48 & 14 & 87 & 140 & 384 & 59 \\
\hline 40 & 20 & 56 & 15 & 88 & 142 & 390 & 60 \\
\hline 41 & 23 & 63 & 16 & 89 & 144 & 396 & 61 \\
\hline 42 & 26 & 71 & 17 & 90 & 147 & 403 & 62 \\
\hline 43 & 28 & 78 & 18 & 91 & 149 & 409 & 63 \\
\hline 44 & 31 & 86 & 19 & 92 & 151 & 415 & 63 \\
\hline 45 & 34 & 93 & 20 & 93 & 153 & 422 & 64 \\
\hline 46 & 37 & 101 & 21 & 94 & 156 & 428 & 65 \\
\hline 47 & 39 & 108 & 22 & 95 & 158 & 434 & 66 \\
\hline 48 & 42 & 116 & 23 & 96 & 160 & 440 & 67 \\
\hline 49 & 45 & 123 & 24 & 97 & 162 & 447 & 68 \\
\hline 50 & 47 & 131 & 25 & 98 & 165 & 453 & 68 \\
\hline 51 & 50 & 138 & 26 & 99 & 167 & 459 & 69 \\
\hline 52 & 53 & 145 & 27 & 100 & 169 & 465 & 70 \\
\hline 53 & 55 & 152 & 28 & 101 & 171 & 471 & 71 \\
\hline 54 & 58 & 160 & 29 & 102 & 174 & 478 & 72 \\
\hline 55 & 61 & 167 & 30 & 103 & 176 & 484 & 73 \\
\hline 56 & 63 & 174 & 31 & 104 & 178 & 490 & 73 \\
\hline 57 & 66 & 181 & 32 & 105 & 180 & 496 & 74 \\
\hline 58 & 68 & 188 & 33 & 106 & 183 & 502 & 75 \\
\hline 59 & 71 & 195 & 34 & 107 & 185 & 508 & 76 \\
\hline 60 & 74 & 202 & 35 & 108 & 187 & 514 & 77 \\
\hline 61 & 76 & 209 & 36 & 109 & 189 & 520 & 78 \\
\hline 62 & 79 & 216 & 36 & 110 & 191 & 526 & 78 \\
\hline 63 & 81 & 223 & 37 & 111 & 193 & 532 & 79 \\
\hline 64 & 84 & 230 & 38 & 112 & 196 & 538 & 80 \\
\hline 65 & 86 & 237 & 39 & 113 & 198 & 544 & 81 \\
\hline 66 & 89 & 244 & 40 & 114 & 200 & 550 & 82 \\
\hline 67 & 91 & 251 & 41 & 115 & 202 & 556 & 82 \\
\hline 68 & 94 & 258 & 42 & 116 & 204 & 562 & 83 \\
\hline 69 & 96 & 265 & 43 & 117 & 206 & 568 & 84 \\
\hline 70 & 99 & 271 & 44 & 118 & 208 & 574 & 85 \\
\hline 71 & 101 & 278 & 45 & 119 & 211 & 580 & 85 \\
\hline 72 & 104 & 285 & 46 & 120 & 213 & 586 & 86 \\
\hline 73 & 106 & 292 & 47 & 121 & 215 & 592 & 87 \\
\hline 74 & 109 & 298 & 48 & 122 & 217 & 598 & 88 \\
\hline 75 & 111 & 305 & 49 & 123 & 219 & 603 & 89 \\
\hline 76 & 113 & 312 & 49 & 124 & 221 & 609 & 89 \\
\hline 77 & 116 & 318 & 50 & 125 & 223 & 615 & 90 \\
\hline 78 & 118 & 325 & 51 & 126 & 225 & 621 & 91 \\
\hline 79 & 121 & 332 & 52 & 127 & 227 & 627 & 92 \\
\hline 80 & 123 & 338 & 53 & 128 & 230 & 633 & 92 \\
\hline
\end{tabular}

$T$, temperature at the extraction point $\left({ }^{\circ} \mathrm{C}\right) ; \mathrm{WCH}, \mathrm{W}$-cost of heat $\left(\mathrm{kW}_{\mathrm{e}}\right.$ of "missed electricity production" per $\mathrm{MW}_{\mathrm{th}}$ supplied to the process); QCH, Q-cost of heat ( $\mathrm{kW}_{\text {th }}$ of additional core thermal power per $\mathrm{MW}_{\text {th }}$ supplied to the process); $\mathrm{ECH}, \mathrm{E}$-cost of heat $\left(\mathrm{kW}_{\mathrm{e}}\right.$ of electricity per $\mathrm{MW}_{\mathrm{th}}$ supplied to the process). 


\section{References}

1. GWI, IDA Desalination Yearbook 2012-2013 (Global Water Intelligence, 2012)

2. R. Semiat, Energy issues in desalination processes, Environ. Sci. Technol. 42, 8193 (2008)

3. M. Elimelech, Seawater desalination, in NWRI Clarke Prize Conference, Newport Beach, California, 2012, available online at: http://www.nwri-usa.org/documents/Elimelech_000.pdf

4. S. Miller, H. Shemer, R. Semiat, Energy and environmental issues in desalination, Desalination 366, 2 (2014)

5. S. Burn, M. Hoang, D. Zarzo, F. Olewniak, E. Campos, B. Bolto, O. Barron, Desalination techniques - a review of the opportunities for desalination in agriculture, Desalination 364, 2 (2015)

6. G.M. Zak, Thermal desalination: structural optimization and integration in clean power and water, Doctoral dissertation, Massachusetts Institute of Technology, 2012

7. A. Al-Karaghouli, L.L. Kazmerski, Energy consumption and water production cost of conventional and renewable-energypowered desalination processes, Renew. Sustain. Energy Rev. 24, 343 (2013)

8. M. Rognoni, M.P. Ramaswamy, J.R. Paden, Energy cost for desalination evaporation versus reverse osmosis, Int. J. Nucl. Desalin. 4, 277 (2011)

9. IEA, OECD, NEA, Projected Costs of Generating Electricity - 2010 Edition (International Energy Agency and Nuclear Energy Agency, France, 2010)
10. H. Safa, Economics of district heating using light water reactors, in NEA/IAEA Workshop on Nuclear Cogeneration, Paris, 4-5 April 2013, 2013, available online at: http://www. oecd-nea.org/ndd/workshops/nucogen/presentations/4_Safa_ Economics-District-Heating-Light.pdf

11. S. Nisan, S. Dardour, Economic evaluation of nuclear desalination systems, Desalination 205, 231 (2007)

12. W. Wagner, J.R. Cooper, A. Dittmann, et al., The IAPWS industrial formulation 1997 for the thermodynamic properties of water and steam, J. Eng. Gas Turbines Power 122, 150 (2000)

13. M.H. Sharqawy, J.H. Lienhard, S.M. Zubair, Thermophysical properties of seawater: a review of existing correlations and data, Desalin. Water Treat. 16, 354 (2010)

14. J. Black, Capital Cost Scaling Methodology (NETL, DOE, USA, 2013)

15. F. Gaudier, URANIE: the CEA/DEN uncertainty and sensitivity platform, Proc. Soc. Behav. Sci. 2, 7660 (2010), URANIE is available online at: http://sourceforge.net/projects/uranie/

16. K.C. Kavvadias, I. Khamis, The IAEA DEEP desalination economic model: a critical review, Desalination 257, 150 (2010)

17. M. Ahmed, A. Arakel, D. Hoey, M. Thumarukudy, M. Goosen, M. Al-Haddabi, A. Al-Belushi, Feasibility of salt production from inland RO desalination plant reject brine: a case study, Desalination 158, 109 (2003)

18. A. Dindi, D. Viet Quang, M. Abu-Zahra, Simultaneous carbon dioxide capture and utilization using thermal desalination reject brine, Appl. Energy 154, 298 (2015)

Cite this article as: Saied Dardour, Henri Safa, Energetic and economic cost of nuclear heat - impact on the cost of desalination, EPJ Nuclear Sci. Technol. 3, 1 (2017) 